\title{
Nuevos modelos de mujer en la fotonovela del tardofranquismo
}

\section{New female models in the photo-novel of late Francoism}

\author{
Irene Holguín Gómez \\ Investigadora independiente
}

Fecha de recepción: 5 de noviembre de 2018

Anuario del Departamento de Historia y Teoría del Arte

Fecha de aceptación: 15 de enero de 2019

vol. 29-30, 2017-2018, pp. 67-92

ISSN: 1130-5517, eISSN: 2530-3562

http://doi.org/10.15366/anuario2017-2018.29-30.03

\begin{abstract}
RESUMEN
El presente trabajo es el resultado del análisis visual de fotonovelas publicadas en los últimos años del régimen franquista. Su objetivo es ver de qué manera la fotonovela construyó, junto a otros muchos mecanismos, la identidad de la mujer durante el tardofranquismo. Hay que tener en cuenta que a partir de los años cincuenta la mujer se está empezando a introducir en la sociedad de consumo y en el mercado laboral. Debido a esto, la fotonovela constituye un buen ejemplo de las paradojas que se dan en la emancipación de la mujer dentro de la sociedad de consumo. Se han seleccionado dos casos de estudio significativos: la colección Corín Tellado (1966-1974) y Simplemente María (1972-1973). Ambas fotonovelas se analizarán con un enfoque crítico feminista y se examinarán comparativamente para sacar las conclusiones finales.
\end{abstract}

\section{PALABRAS CLAVE}

Fotonovela. Tardofranquismo. Revista femenina. Sociedad de consumo. Emancipación de la mujer. Feminismo.

\begin{abstract}
The present work is the result of the visual analysis of the photo-novels published in the last years of the Franco regime. The objective is to analyze how the photo-novel built, together with many other mechanisms, the identity of women during the late Francoism. It must be noted that since the 1950 s, women had begun to be introduced to the consumer society and to the labor market. Thus, the photo-novel is a good example of the paradoxes that occurred in the emancipation of women in the consumer society. To be able to comment on these changes, two important case studies have been analyzed: The Corin Tellado collection (1966-1974) and Simplemente María (19721973). These photo-novels will be examined from a critical feminist approach and conclusions will be drawn through their comparison.
\end{abstract}

\section{KEY WORDS}

Photo-novel. Late Francoism. Women's magazines. Consumer society. Emancipation of women. Feminism. 


\section{Introducción ${ }^{1}$}

A partir de los años cincuenta en España se empieza a implantar la sociedad de consumo y se inicia una nueva etapa de ayuda y diálogo con Norteamérica ${ }^{2}$. En contraste con el anterior periodo político de autarquía en la que se había producido un retroceso de la mujer al hogar ${ }^{3}$, la mujer incrementó su presencia en el mercado laboral y se intensificó su papel como consumidora ${ }^{4}$. Todos estos cambios socio-económicos redefinieron el papel de la mujer en el espacio público y sus representaciones en los medios de comunicación hegemónicos. Buen ejemplo de esto último son las fotonovelas publicadas entre mediados de los años sesenta y los setenta en España.

Las fotonovelas, como bien es sabido, se caracterizan por ser una secuencia de imágenes fotográficas fijas que, mediante la utilización de texto, forman un relato. Están dirigidas principalmente a mujeres y son en su mayoría de contenido amoroso (fig. 1). En España, algunas de las primeras manifestaciones las encontramos alrededor de los años cincuenta. Por una parte, influenciadas por la industria cinematográfica y el auge del cine, algunas revistas comerciales utilizaban estrategias narrativas fotonovelísticas para dar consejos, contar historias o, en la mayoría de los casos, para poder incluir en revistas comerciales una película de éxito de forma completa. Por otro lado, a finales de los cincuenta, incitadas por el triunfo de la fotonovela en otros países como Italia, se publican sin éxito algunas revistas "femeninas" especializadas en el género. Por ejemplo, la revista "femenina" Picnic -de especial interés para entender las nuevas aspiraciones de la sociedad española, fuertemente condicionadas por la promesa de triunfo a través del estrellatopromovía la participación de los lectores y lectoras a través de su concurso "Picnic busca una estrella". En él se escogía de entre los participantes un actor y actriz para protagonizar su nueva fotonovela. "Picnic busca una estrella" se vendía como un medio para acceder a la fama mundial a través de la fotonovela, del mismo modo que le había ocurrido a Gina Lollobrigida a finales de los cuarenta en Italia ${ }^{5}$.

A pesar de estos primeros intentos, la fotonovela en España tiene que esperar a los años sesenta con la consolidación de la cultura de consumo para que surjan colecciones de fotonovelas de éxito. Entonces Rollán, una editorial ubicada en Madrid y especializada en la venta de tebeos y libros de bolsillo, lanzó al mercado las adaptaciones de la exitosa novelista del género rosa Corín Tellado en la colección homónima Corín Tellado (1966-1974) con mucho éxito ${ }^{6}$. Paralelamente, distintas editoriales como Bruguera, Editormex o Ediciones Alonso editaron fotonovelas con un formato parecido, se trató de lo que las propias colecciones denominaron "fotonovela completa" en las que el argumento solo abarcaba un número de la colección. Posteriormente, en 1972, se publica Simplemente María por parte de la editorial Sedmay que inaugurará un nuevo modelo editorial con sus características propias como puede ser su publicación por entregas, es decir, que la historia se desarrollaba a lo largo de los números de la colección. Para entender la fotonovela hay que tener presente el cambio de paradigma que se está dando en la industria editorial en aquellos años. El aumento del poder adquisitivo de las mujeres de la época provoca que empresas y editoriales se interesen por la mujer como consumidora. Esto avivó la proliferación de los ya existentes productos culturales "femeninos" que pensaban en la mujer como lector ideal.

\footnotetext{
1 Este artículo es una parte de la investigación realizada en Irene Holguín GómEz, "Nuevos modelos de mujer en la fotonovela del tardofranquismo", Trabajo de Fin de Máster, Madrid, Universidad Autónoma de Madrid, Universidad Complutense de Madrid, Museo Nacional Centro de Arte Reina Sofía, 2018. Querría dar las gracias a Noemi de Haro García, tutora de este TFM, y a los tres miembros del tribunal, Jesusa Vega, Jesús Carrillo y José Luis S. Noriega por sus sugerencias y comentarios.

${ }^{2}$ Lourdes Benería, Mujer, economía y patriarcado durante la España franquista, Barcelona, Anagrama, 1977, pp. $33-34$.

3 Carmen Martín Gaite, Usos amorosos de la postguerra española, Barcelona, Anagrama, 2000, p. 52.

${ }^{4}$ BENERÍA, 1977, p. 44.

5 "Picnic busca una estrella", Picnic, 1 (1958), p. 2.

6 Juan Antonio Ramírez se refiere específicamente a "las monstruosas tiradas alcanzadas por algunas de estas fotonovelas" que llegaban a los 150.434 ejemplares en la colección de Corín Tellado en 1967. Juan Antonio RAMírEz, El "cómic” femenino en España: arte sub y anulación, Madrid, Edicusa, 1975, p. 226.
} 

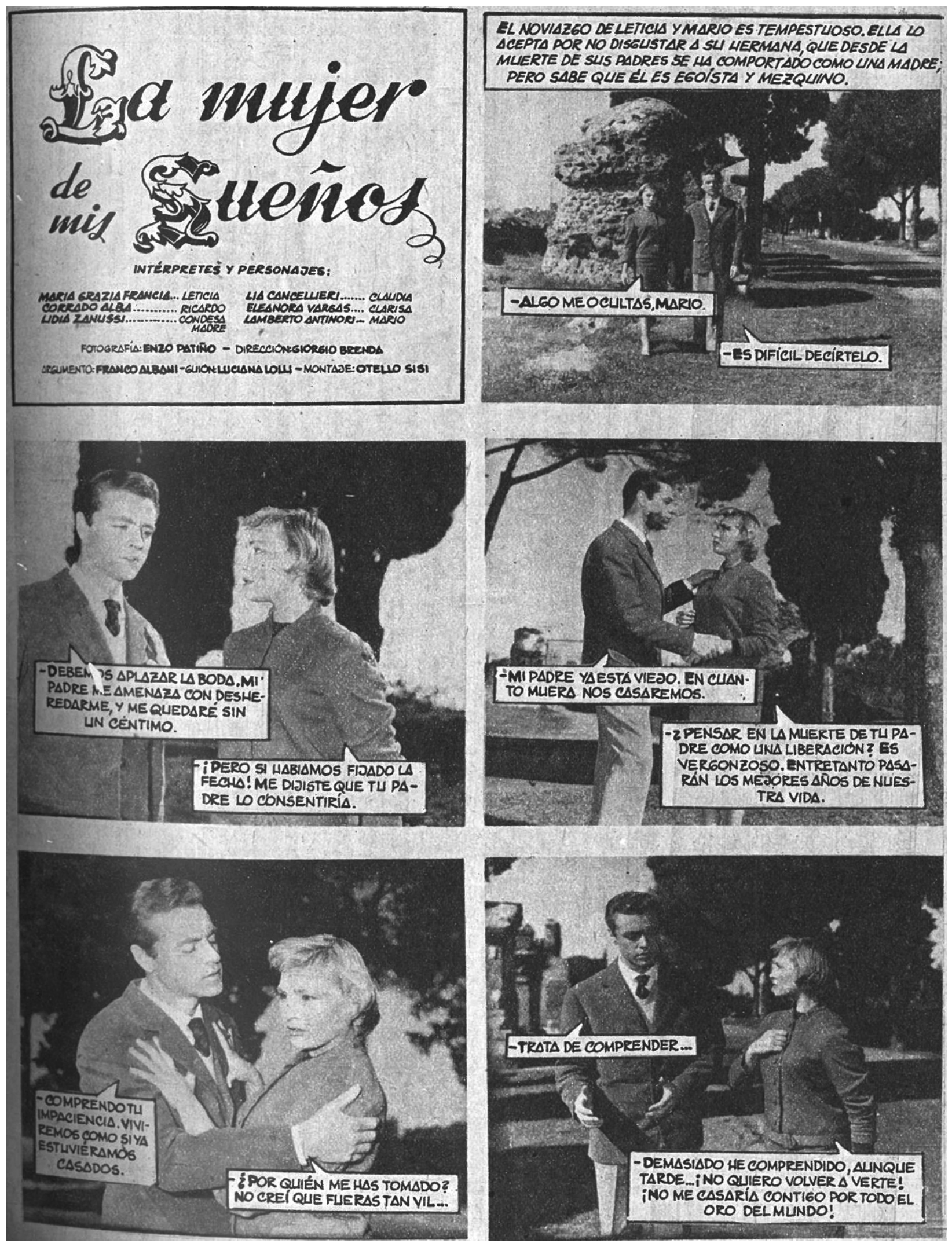

Fig. 1. "La mujer de mis sueños", Picnic, 11 (1959), p. 13. 
Antes de continuar, cabe hacer un inciso y recalcar lo problemático de esta concepción de lo "femenino" desde un enfoque crítico feminista. Por una parte, porque es resultado de la diferencia sexual y de los roles adjudicados a lo "masculino" y lo "femenino"7 y, además, porque no se trata solo de que se dirijan a mujeres sino de que estas publicaciones tengan contenidos principales considerados "femeninos" como los amorosos, la moda, el hogar, el consultorio, el horóscopo, etc. ${ }^{8}$ Es por este motivo por el cual la fotonovela se incluye entre los géneros "femeninos" aunque no lo lleve explícitamente en el nombre.

Con todo, cabe preguntarse, ¿eran solo las mujeres quienes prestaban atención a estos productos "femeninos"? Tal y como establece Juan Antonio Ramírez muchos de sus lectores, en especial los de género masculino y las clases mejor dotadas, mantenían su lectura en secreto debido a las "connotaciones sociales negativas que acompañan a esta clase de lecturas" . O no tan en secreto, ya que, como relata la actriz del serial radiofónico Simplemente María, durante su emisión varios taxistas en Córdoba llevaban un cartel que decía "Por favor, no molesten de cuatro y media a cinco. Estoy escuchando Simplemente María"10. A pesar de que muchas de estas colecciones utilizaban giros como "queridas amigas..." o "tú mujer..." para dirigirse en segunda persona a un público exclusivamente compuesto por mujeres, parecían del mismo modo interesadas en demostrar que también los hombres leían sus revistas. Por ejemplo, en Simplemente María se publica un poema enviado por un taxista ${ }^{11}$. Otro ejemplo de esto lo encontramos en el consultorio que supuestamente respondía la misma escritora de la colección de fotonovelas Corín Tellado donde se ha podido observar que aproximadamente un 7\% de las preguntas eran hechas por hombres. En una de las respuestas, encontramos que Corín Tellado recalca y celebra esta gran proporción de cartas firmadas por nombres masculinos; no obstante, considera que el interés del autor de la consulta en las fotonovelas es el de "descubrir el mundo íntimo de la mujer", un mundo que estaría oculto para ellos de otra manera ${ }^{12}$. Esta misma diferenciación la hemos encontrado en los testimonios de la actriz protagonista de Simplemente María quien relata que los hombres la paraban por la calle para que les firmase la camisa alegando que lo hacían para "dar una satisfacción a su mujer"13.

Dentro del mundo intelectual se localizaban las lecturas de Corín Tellado por un público masculino en los cuarteles y el servicio militar ${ }^{14}$. La razón de esto, se argumentaba, era la imposibilidad de acceder a otras publicaciones con carga erótica ${ }^{15}$. Fuera como fuese, parece que eran muchos los motivos (explícitos o no) por los que los hombres también se contaban entre los consumidores de estos productos. Sin embargo, las motivaciones que se referían para unos y otras se presentaban siempre asociadas a intereses diferentes, frecuentemente diametralmente opuestos. Mientras que las lectoras de fotonovelas eran ridiculizadas y criticadas, no sucedía lo mismo con los hombres. Para señalar y problematizar el carácter construido de lo que se presenta como "femenino" de la fotonovela y de su público, en este artículo siempre entrecomillaremos el término.

Simultáneamente a la consolidación de estos productos "femeninos", escritoras como Corín Tellado, Delia Fiallo y Celia Alcántara, las dos autoras de las novelas de donde provenían algunos de los seriales radiofónicos o fotonovelas de los setenta y de muchas de las telenovelas de mayor repercusión por todo el

\footnotetext{
7 María Isabel MenÉndeZ y Mónica Figueras, "La evolución de la prensa femenina en España. De La pensadora gaditana a los blogs", Comunicació: Revista de Recerca i d'Anàlisi (2012), p. 28.

${ }^{8}$ Covadonga Pendones, "Estrategias discursivas en las revistas femeninas", en La Lengua y los medios de comunicación: actas del Congreso Internacional celebrado en la Universidad Complutense de Madrid en 1996 (Madrid,1966), Madrid, Universidad Complutense de Madrid, Servicio de Publicaciones, 1999, p. 311.

9 RAMíreZ, 1975, p. 229.

10 Manuel María Meseguer, "María o la supervivencia del folletín”, $A B C$ (13 de mayo, 1973), p. 216.

11 “Queridas amigas...", Simplemente María, 16 (1972), p. 2.

12 Corín Tellado, “Corín Tellado contesta a...", Corín Tellado, 5 (1966), p. 2.

13 CAMPOS, 1975, p. 138.

14 Tal y como establecen tanto Juan Antonio Ramírez como Andrés Amorós en Ramírez, 1975, p. 226 y Andrés Amorós, Subliteraturas, Barcelona, Ariel, 1974, p. 188.

15 Andrés Amorós, "La rúbrica de la novela romántica", El Mundo (12 de Abril de 2009) [en línea], https:/www.elmundo.es/elmundo/2009/04/12/opinion/2628031.html [Consulta: 1 de noviembre de 2018].
} 
mundo, empiezan a superar en ventas a muchos otros escritores de renombre. Estas escritoras y profesionales de éxito, tienen independencia económica y son posibles referentes para una nueva generación de mujeres que ya no se sentían cómodas en la retórica del ángel del hogar. En concreto la escritora asturiana Corín Tellado fue una de las novelistas con mayores ventas durante los años sesenta en España y posteriormente en América Latina. En España, sacaba una novela cada semana, con unos 100.000 ejemplares por cada tirada ${ }^{16}$. A ello hay que sumar las fotonovelas de la colección que presentamos como caso de estudio, así como los textos que publicaba en otras revistas ${ }^{17}$. Todo esto demuestra la creciente importancia del público "femenino" durante los años sesenta y, además, el papel central que jugó Corín Tellado a partir de la mitad del siglo XX. El nombre de Corín Tellado, al igual que el de otros personajes femeninos de la época, funcionó como un reclamo publicitario y como una marca editorial para una multitud de productos además de las novelas, como las fotonovelas, los cuentos, los consultorios y hasta un serial radiofónico ${ }^{18}$.

A pesar del innegable triunfo profesional de toda esa generación de mujeres escritoras, los productos culturales "femeninos" han tenido una serie de connotaciones negativas en las que se asocia la feminidad con la baja cultura que han provocado que no se les preste demasiada atención o que se las aborde desde un tono despectivo y paternalista ${ }^{19}$ Es más, tanto las lectoras como las propias colecciones fueron ridiculizadas. Esto se puede ver, por ejemplo, en el argumento de Lo Sceicco Bianco del autor de culto Federico Fellini, en el que caricaturiza la obsesión que siente la protagonista por su personaje de fotonovelas preferido $^{20}$. En su edición inglesa de la novela Los jueves con Leila de Corín Tellado, Diana Holmes y Duncan Wheeler se hacen eco de las investigaciones de Jo Labanyi sobre las lecturas "femeninas" en España a principios de siglo XX y sitúan las causas de esto en que este tipo productos son consumidos por un público subalterno que, en el caso de la fotonovela, se supone mayoritariamente femenino o de clase baja ${ }^{21}$.

Esta mirada androcéntrica hacia lo "femenino" también es la predominante a la hora de enjuiciar a las lectoras cuyos intereses (aunque de forma problemática) eran recogidos por revistas, fotonovelas y radionovelas de la época. En el caso concreto de la fotonovela, quienes se interesaron por la fotonovela desde su origen hasta mediados de los setenta hablaron de ella en términos negativos. Esto fue así tanto cuando se hizo desde la academia, al calor de la fascinación que sintieron muchos investigadores por la expansión de los medios de comunicación, como cuando se escribió sobre ella desde ciertos medios de comunicación hegemónicos, como pueden ser periódicos comerciales ${ }^{22}$. Muchos de estos ataques se apoyaron en la idea de que era un producto alienante y dañino para la mujer. Por ejemplo, Juan Antonio Ramírez en su capítulo dedicado a la fotonovela, "Del tebeo a la fotonovela. La revista femenina" en El "cómic" femenino en España: arte sub y anulación habla de la fotonovela como algo que predica "la omnipotencia del 'amor'. Pero este amor es patrimonio de la 'mujer sumisa' que acepta sin discusión los valores más reaccionaros y que, a cambio de sus sacrificios y de su adhesión al orden establecido, conseguirá enamorar al jefe o a cualquier otro galán"23. Este tipo de análisis presenta una imagen basada en estereotipos en los que se deforman y simplifican los personajes femeninos presentados en las publicaciones de la época. Como veremos

\footnotetext{
16 Andrés Amorós, Sociología de una novela rosa, Madrid, Taurus, D. L. 1968, p. 12.

17 Por ejemplo, en Selene (1967) encontramos un cuento escrito por la autora y otro consultorio similar al de "Corín Tellado contesta a..." que se publicaba dentro de la colección Corín Tellado y del que hablaremos más adelante.

18 "Corín Tellado, un serial radiofónico", $A B C$ (6 de abril de 1977), p. 53.

19 Duncan WheEler y Diana Holmes, “Introduction”, en Thursdays with Leila, Cambridge, The Modern Humanities Research Association, 2016, p. 2.

20 Lo sceicco bianco (Federico Fellini, 1952).

21 Wheeler y Holmes, 2016, p. 2.

22 Dentro de la academia encontramos por ejemplo el capítulo de Juan Antonio RAMÍREZ," Del tebeo a la fotonovela. La revista femenina", en El “cómic” femenino en España: arte sub y anulación, Madrid, Edicusa, 1975, pp.219-234 o Manuel J. CAMPO, "Simplemente María” y su repercusión entre las clases trabajadoras. Barcelona. Avance, 1975. Dentro de los periódicos comerciales el interés en este género llegó inmediatamente a su expansión como por ejemplo en el periódico del ABC en Ángel María LERA, "Monstruos literarios. La fotonovela", Suplemento semanal de crítica e información del $A B C$ (24 de agosto de 1967), p. 15.

23 RAMIREZ, 1975, 233.
} 
a continuación, la fotonovela demuestra cómo desde la industria cultural se construyó cierta concepción de la emancipación en la que presenta a personajes femeninos con comportamientos que no corresponden con el estereotipo de la "mujer sumisa" como bien puede ser trabajar, fumar o conducir su propio coche. Por otro lado, a pesar de que otros autores sí analizan en más profundidad los personajes femeninos no existe en sus textos una relación entre estas críticas y las estructuras patriarcales de la época. Este sería el caso de Manuel J. Campo en sus observaciones sobre Simplemente María, Pedro Sempere en el de Lucecita o Amorós en sus estudios de la colección de Corín Tellado ${ }^{24}$.

Hay que tener en cuenta de que paralelamente se están dando los debates sobre la diferencia sexual y sus causas a raíz de la conocida tesis de Simone de Beauvoir en la publicación en 1949 del Segundo Sexo ${ }^{25}$. Existe un revulsivo de manifestaciones feministas como es el caso del feminismo radical en los años setenta en Estados Unidos en que las que teóricas se desligan de los movimientos de izquierdas aplicando la metodología marxista para explicar cómo se construyen las relaciones de poder en relación al género, el sexo y la configuración y definición del patriarcado. Este interés por entender cómo se construye la subjetividad femenina en la sociedad de consumo sí la encontramos dentro de los debates en el campo artístico en España. En los años sesenta y setenta hallamos propuestas desde la práctica artística en las que se denuncia la objetualización de la mujer o la restructuración de las relaciones de poder en el patriarcado con la llegada de la sociedad de consumo. Desde esta perspectiva, varias artistas analizaron el papel de los medios de comunicación hegemónicos en la construcción del imaginario de la mujer en la sociedad de consumo, por ejemplo, en la exposición de Ana Peters en 1966 Imágenes de la mujer en la sociedad de consumo en la Galería Edurne o más tarde la obra Fin (1978) en la que Eugènia Balcells utiliza la última viñeta de varias de varias fotonovelas para resumir la infértil promesa del amor romántico ${ }^{26}$.

Esta investigación considera que el interés de la fotonovela radica precisamente en ser uno de los productos de mayor expansión entre las mujeres en el tardofranquismo y que como tal, contribuye a la construcción de una imagen de la inserción de la mujer en la sociedad de consumo en España que llegó a un gran número de personas. Debido a esto, la fotonovela es de gran relevancia para analizar desde un enfoque crítico feminista el imaginario de lo "femenino" en el tardofranquismo, así como para debatir las paradojas que existen en la construcción de la subjetividad femenina dentro de las lógicas de mercado. En el caso concreto de la fotonovela encontramos una visión muy determinada de la feminidad, asociada a la cultura de consumo que adopta comportamientos que son contestatarios solo en apariencia. Por esta razón, a nuestro juicio, la fotonovela es un claro ejemplo de cómo se puede configurar desde la industria cultural una visión muy concreta del progreso y la emancipación de la mujer que no cuestiona realmente las concepciones tradicionales de madre o esposa. Todo esto demuestra cómo existe en esos años cierta construcción de la feminidad que se cimienta en múltiples discursos contradictorios y paradójicos. A nuestro parecer, al igual que lo "femenino", estas nociones de progreso y emancipación de la mujer son producto de un contexto específico.

Para poder analizar todas estas cuestiones, tras realizar un exhaustivo examen de muestras en el cual se han consultado 14 colecciones de fotonovelas (publicadas entre 1965 y 1977) y 216 ejemplares de revistas "femeninas" de la época (aparecidas entre 1950 y 1961), se han seleccionado como casos de estudio las dos fotonovelas con mayor repercusión e influencia en esos años: la colección de Rollán Corín Tellado (1966-1974), concretamente los dieciocho primeros números de la misma publicados entre 1966 y 1967, y la colección completa de la editorial Sedmay Simplemente María (1972-1973) ${ }^{27}$. Estos dos casos de estu-

\footnotetext{
24 CAmpo, 1975; Pedro Sempere, Semiología del infortunio: lenguaje e ideología en la fotonovela, Madrid, Felmar, 1976. Andrés Amorós, Subliteraturas, Barcelona, Ariel, 1974.

25 Simone DE BeAuvorr, Le Deuxième Sexe. Tome 1. Les Faits et les mites, París, Gallimard, 1949.

${ }^{26}$ Eugènia BALCELls, "Eugènia Balcells. La utopía como laboratorio", Arte y politicas de identidad, vol. 1 (diciembre 2009$)$, p. 264 [en línea], http://revistas.um.es/api/article/viewFile/89501/86521 [Consulta: 1 de noviembre de 2018].

${ }^{27} \mathrm{El}$ impacto de ambas fotonovelas se aprecia en el interés que suscitaron tanto en textos académicos como no académicos, de hecho, algunos de estos trabajos académicos se referían explícitamente a la gran repercusión de estas fotonovelas: la de Corín Tellado
} 
dio plantean dos problemáticas muy diferentes de la emancipación de la mujer en esos años, por lo que creemos que es de gran relevancia analizar cómo se reprodujeron esas paradojas visualmente en cada uno de los casos para poder posteriormente examinarlos comparativamente en las conclusiones finales. Además de por su enfoque, esta investigación resulta pionera puesto que, a pesar de la existencia de un buen número de publicaciones que se ocuparon de la fotonovela entre los años 1973 y 1976 en España, ninguna de ellas ha partido de una revisión de materiales comparable a la que aquí proponemos.

\section{Corín Tellado. La llegada de Hollywood y la sociedad de consumo}

A través de sus novelas la escritora Corín Tellado apostó por una construcción muy determinada de la feminidad. Se trataba de mujeres que conducían su propio coche, fumaban y que adoptaban actitudes fuera de lo que en la época se podría considerar tradicional. Estos personajes, junto a ciertos elementos como pueden ser la estructura del relato, la idealización del amor romántico y el lujo o el ambiente consumo ${ }^{28}$, formaron la identidad propia que caracterizaba la producción de esta autora. La editorial Rollán al adaptar las novelas a la colección de fotonovelas de Corín Tellado no dudó en repetir la fórmula de éxito que había creado la novelista, esta vez a través de una cuidada escenografía y de un elenco de actrices como Conchita Cura, Mariló Punti o Esther Riera, que interpretaban a un tipo concreto de personaje que se repetía a lo largo de los números de la colección. Este tipo de personaje femenino es de clase alta, habitualmente estudia en la universidad, utiliza pantalones, en especial vaqueros o los llamados pesqueros o de estilo capri los cuales se hicieron muy populares durante los sesenta, vestidos ajustados y faldas de tubo; todo ello con estampados llamativos, pañuelos en la cabeza (para no despeinarse en el descapotable) y gafas de sol grandes y vistosas. Como puede verse en los planos retrato, suele destacarse de este personaje el maquillaje de los ojos -el rabillo del ojo y las pestañas postizas- lo que, junto al peinado (siempre de peluquería corto o a media melena) y el caro vestuario suelen indicarnos que la protagonista tiene el suficiente tiempo libre y el dinero para permitírselos (fig. 2).

Como ya hemos apuntado, al igual que en las novelas, las protagonistas tienen comportamientos que contradicen la abnegación asociada habitualmente a lo "femenino" como conducir o tener amistades masculinas. No obstante, cabe destacar que este tipo de actitudes las podemos rastrear desde los años cuarenta en España tal y como lo describe Carmen Martín Gaite a través de lo que denominó la "niña topolino", un término que se puede ver por primera vez en 1941 en una caricatura en la revista La Codorniz. El nombre es un desplazamiento semántico del coche de marca FIAT al que se llamaba topolino ("ratoncito" en italiano), para dar paso a los zapatos topolino de suela grande, tacón bajo y a veces con la puntera descubierta que las caracterizaban. La niña topolino era la representación de la nueva burguesía en España; era el "primer espécimen femenino donde se alentaban las ansias de la futura sociedad de consumo" 29 . Frente al ideal de la mujer prudente, obediente y callada, aquellas chicas desentonaban: la niña topolino adoptaba atuendos chocantes, reía a carcajadas, fumaba y empleaba una jerga similar a la de los chicos ${ }^{30}$. Pese a estas primeras manifestaciones de la "niña topolino", en los años sesenta asistimos a un cambio de paradigma en la construcción de la feminidad de esos años en la que se normalizaron y se aceptaron ciertas actitudes representadas por Corín Tellado. Son los años de la popularización de actrices como Gina Lollobrigida, Sophia Loren, Brigitte Bardot, Audrey Hepburn, Marilyn Monroe o la actriz española Sara Montiel que entonces se estaba empezando a abrir camino en Hollywood, las cuales, como se ha podido

\footnotetext{
era señalada por Juan Antonio Ramírez y la de Simplemente María por Manuel J. del Campo. RAmíREZ, 1975, p. 226; CAMPO, 1975, p. 11.

28 Virginia ERHART, “Amor, ideología y enmascaramiento en Corín Tellado”, Casa de las Américas, 77 (marzo-abril 1973 ), p. 93.

29 Martín Gaite, 2000, p. 78.

30 Martín Gaite, 2000, p. 80.
} 

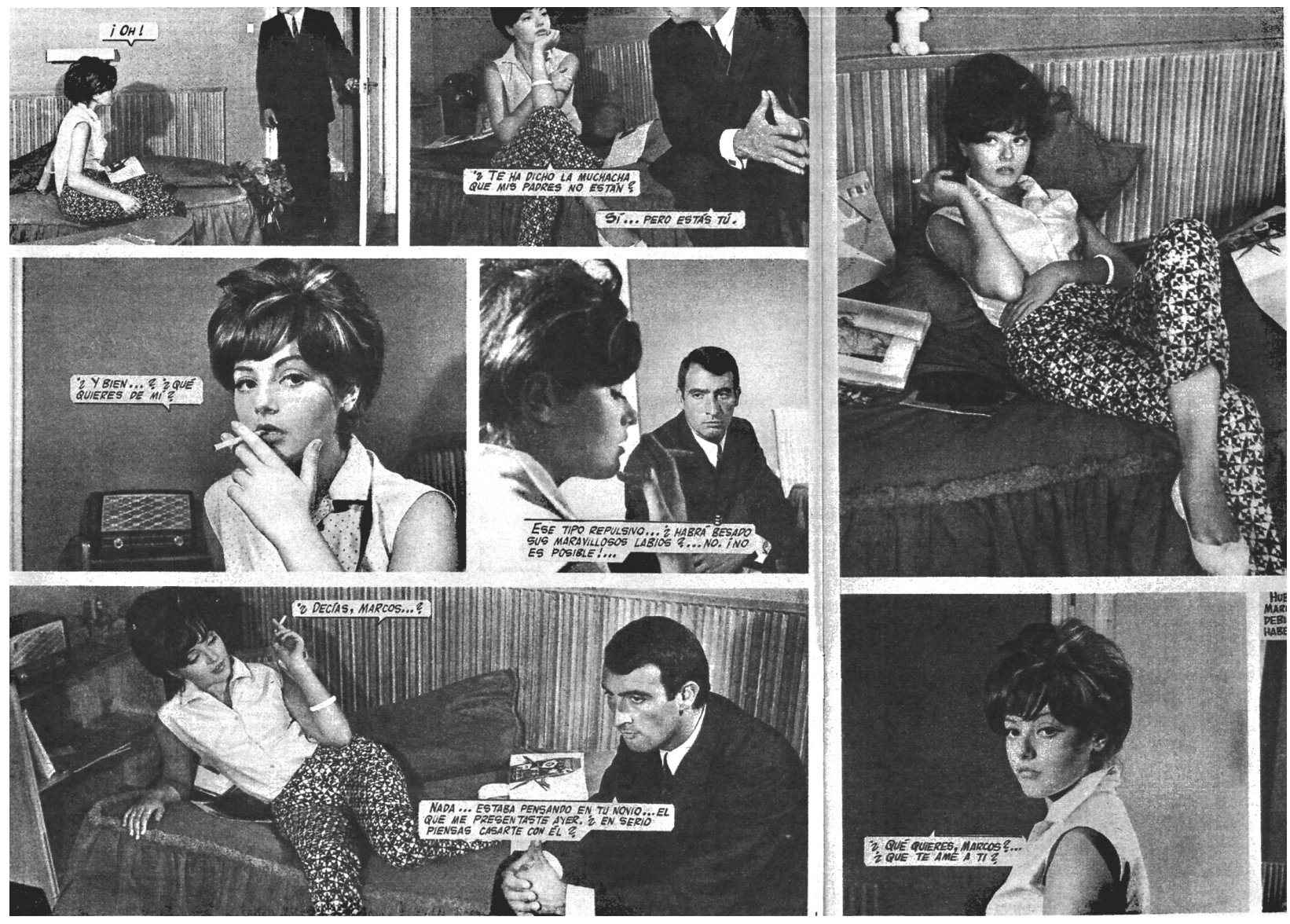

Fig. 2. “Te equivocaste conmigo”, Corín Tellado, 12 (1966), pp. 8-9.

observar a lo largo de la investigación, habían ganado mucho terreno en los productos culturales "femeninos" en España. Al igual que las protagonistas de Corín Tellado, estas actrices se construyeron en base al ideal predominante en Hollywood, a través de la idealización de actitudes aparentemente masculinas como el pelo corto, el uso de pantalones o el tabaco. Por lo tanto, no es de extrañar que estos nuevos estereotipos ayudasen a configurar las características bajo las que se presentaba parte del elenco de las actrices de la editorial Rollán quienes comparten características con las actrices de Hollywood que se acaban de mencionar (figs. 3 y 4). Hay que tener en cuenta la popularización del estilo garçonne en Francia en los años veinte o su expansión posterior bajo el nombre de flapper en Estados Unidos que consistía en un movimiento de las mujeres de clases altas que empezaban a emanciparse e incorporarse al mundo laboral y que subvertían la feminidad precisamente a través de elementos masculinos como el peinado y el vestuario. Estas figuras no se pueden desligar de los personajes que estamos analizando en este artículo. No obstante, tal y como analiza Mercedes Expósito García en De la garçonne a la pin-up, durante los años cuarenta se había producido una progresiva despolitización de la garçonne y la flapper a través de la industria cinematográfica de Hollywood de la que Europa no logró mantenerse al margen. Esto se produjo gracias a una figura de nueva mujer consumidora que condensaba metafóricamente "la esposa, la madre, la casa y el sexo"31.

31 Mercedes Expósito GarcíA, De la garçonne a la pin-up, Madrid, Ediciones Cátedra, 2016, p. 381. 


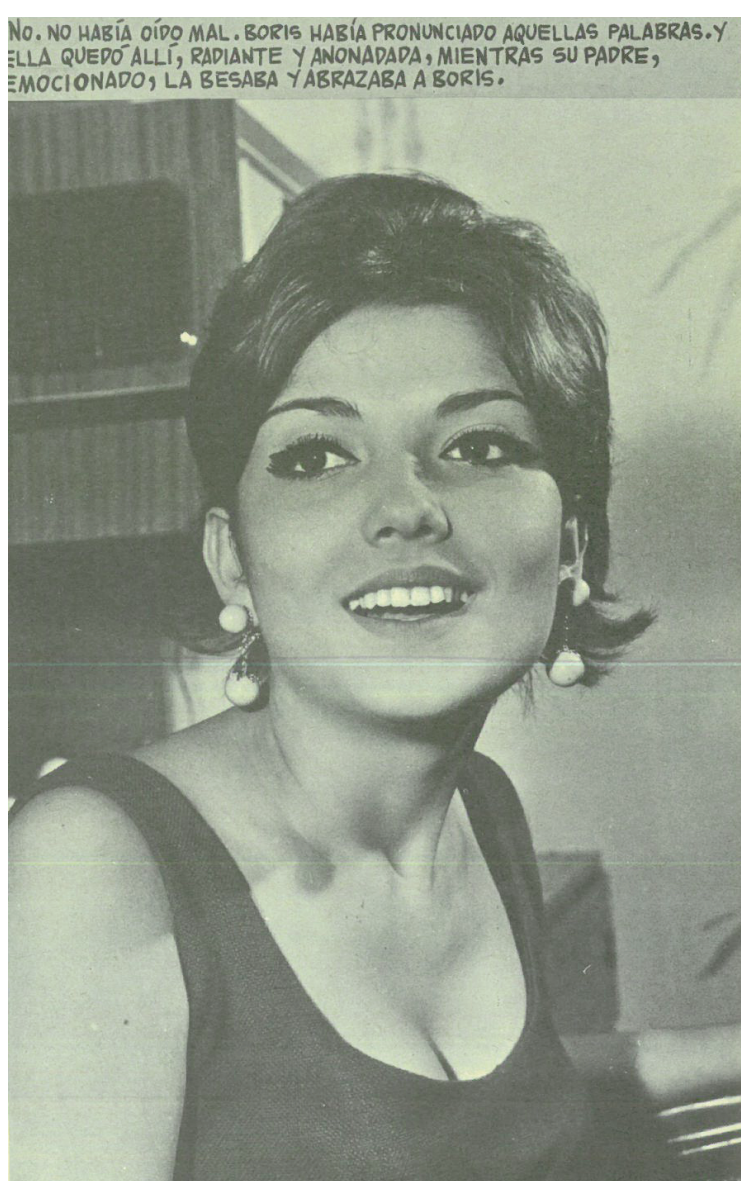

Fig. 3. Esther Riera en "Soy un soltero feliz", Corín Tellado, 1 (1966), p. 65.

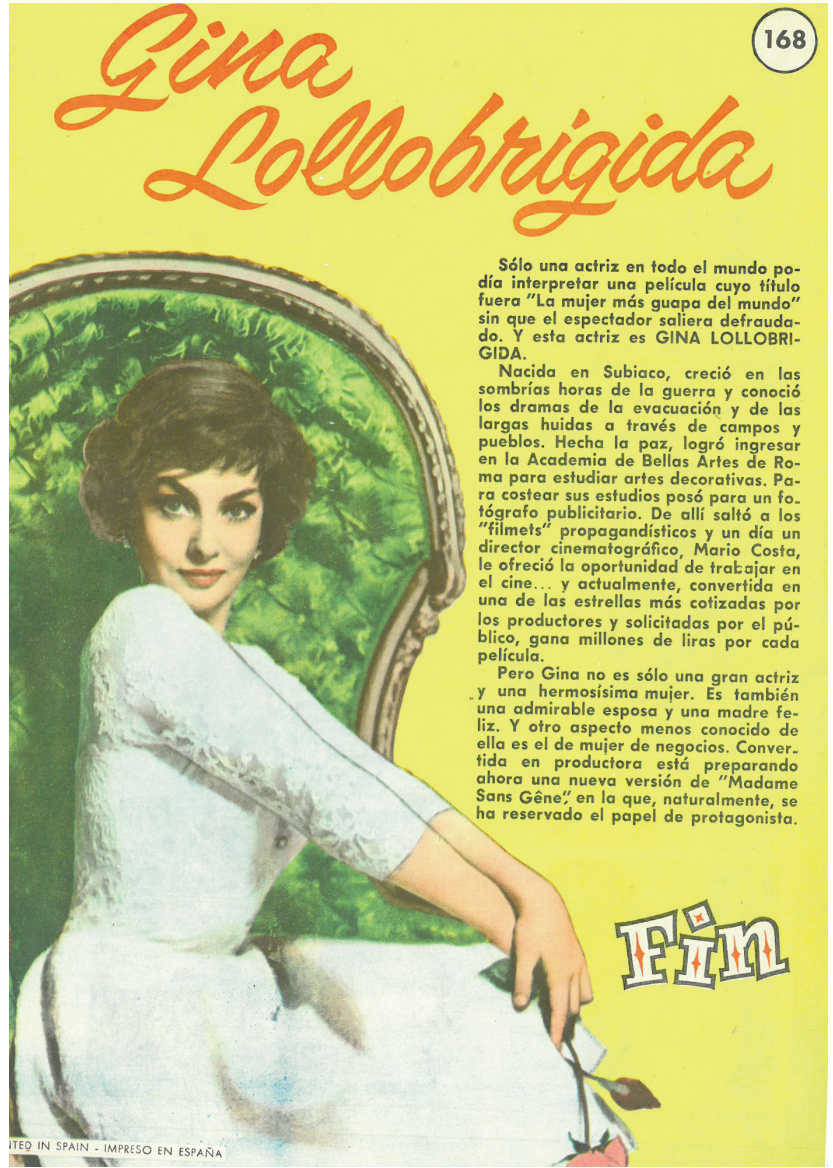

Fig. 4. Gina Lollobrigida en "La vida de Gina Lollobrigida en fotos", Sissi, 168 (1961), p. 20.

Tanto en el caso de estudio propuesto como en los productos culturales "femeninos" de la época podemos encontrar cierta reiteración de estos elementos y actitudes que configuran las convenciones y el concepto de feminidad ligado a las ideas de juventud, elegancia y de mujer nueva y moderna muy parecida a ese modelo de feminidad que venía de Hollywood. Interesante es aquí recuperar los análisis de Judith Butler acerca de la construcción del género. Primero porque establece que la naturalización del género solo es posible mediante la repetición ${ }^{32}$, reiteración que ya hemos visto que encontramos en diversos productos y que tuvieron un papel fundamental en la construcción del género y en la redefinición de lo "femenino" durante en el tardofranquismo en España. La segunda de las ideas propuestas por Butler que nos interesa aquí es la posibilidad de subvertir el género a través de la parodia, es decir, la repetición de elementos que contradicen las nociones normalmente atribuidas a lo masculino y lo femenino. Sobre ello Butler expone:

La parodia por sí sola no es subversiva, y debe de haber una forma de comprender qué es lo que hace que algunos tipos de repetición paródica sean verdaderamente trastornadores, realmente desasosegantes, y que repeticiones pueden domesticarse y volver a ponerse en circulación como instrumentos de hegemonía cultural. Es evidente que no bastaría con una tipología de acciones, ya que el desplazamiento paródico, de hecho, la risa paródica, depende de un contexto y una recepción que puedan provocar confusiones subversivas ${ }^{33}$.

32 Judith Butler, Cuerpos que importan: sobre los límites materiales y discursivos del sexo, Barcelona, Paidós, 2002 , p. 34.

33 Judith ButLer, El género en disputa. El feminismo y la subversión de la identidad, Barcelona, Paidós, 2007, pp. $270-271$. 


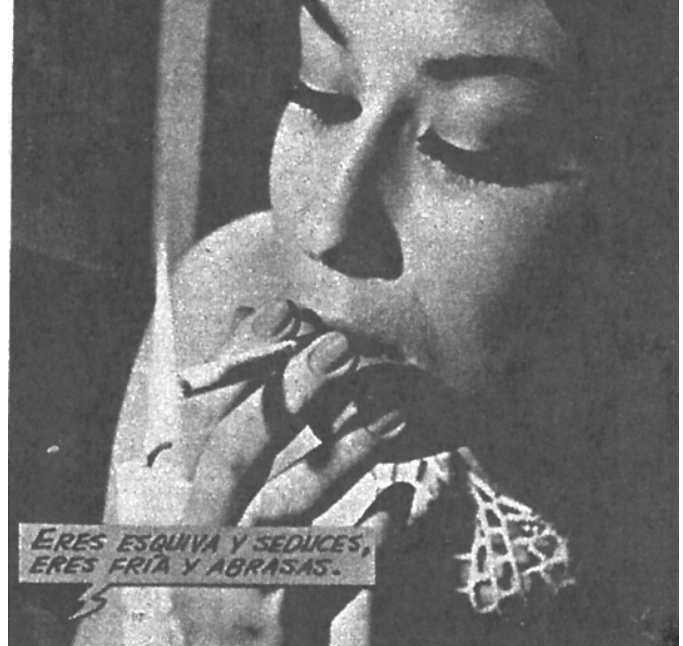

Fig. 5. "Vuelve el ayer", Corín Tellado, 17 (1967), p. 17.
Ante esto cabe preguntarse, ¿subvirtieron las fotonovelas de Corín Tellado los estándares de la época o más bien siguieron el orden hegemónico en el contexto de los años sesenta? Un ejemplo que puede arrojar luz sobre el asunto es el de la mujer fumadora que, tal y como recuerda Carmen Martín Gaite, fue fuertemente rechazada durante la posguerra ${ }^{34}$. No obstante, aproximadamente a partir de los cincuenta existe cierta erotización de la mujer que fuma. Ejemplo conocido es la famosísima escena que había protagonizado Sara Montiel en la película El último cuplé (1957) en la que aparece cantando Fumando espero ${ }^{35}$. Gracias a la capacidad de consumo que las mujeres estaban ganando, la industria tabacalera empieza a mostrar interés por incluir a la mujer dentro de su público consumidor y a realizar campañas en las que se explotaba esta analogía entre la mujer que fuma y la seducción. Esto se reprodujo en la fotonovela que explotaba ese estereotipo de mujer que, especialmente al inicio del relato, resulta enigmática, independiente y distante lo que suele ser atractivo para los personajes masculinos. En realidad, este tipo de mujer la cual no contradecía los estándares asociados a lo "femenino" a la época que, además, seguía los intereses de la industria tabacalera. Por ejemplo, en "Vuelve el ayer" de la colección que aquí nos ocupa, se nos muestra a la protagonista en un plano retrato encendiéndose un cigarro con una vela, con los ojos cerrados mientras que el protagonista masculino le dice "Eres esquiva y seduces, eres fría y abrasas" (fig. 5).

Ciertamente podemos encontrar que esta subversión de los modelos femeninos del primer franquismo está ligada a la incipiente cultura de consumo que estaba calando en España. Algunos de los escenarios más recurrentes son lugares como bares, cafeterías, restaurantes y clubes de baile; todos ellos lugares de ocio ligados a la nueva cultura de consumo y los modos de sociabilidad asociados a ella. Por otro lado, en contraste con el anterior periodo de autarquía, podemos localizar una preferencia por los elementos extranjeros, en especial, por los de países anglosajones. Esto se evidencia en algunos de los nombres de las protagonistas (Ahidee, Meli, Katy, Elka o Marión) o en los lugares en donde se desarrollan algunas fotonovelas: por ejemplo, "Destrúyeme después" se desarrolla en Nueva York según se dice en la propia fotonovela ${ }^{36}$. Quizá uno de los ejemplos más claros de la simbiosis entre la fotonovela y la cultura de consumo sea la práctica de lo que actualmente se denomina emplazamiento publicitario, es decir, la inclusión en las imágenes de productos de marcas visibles y reconocibles para publicitarlos. Por ejemplo, encontramos en un primer plano botellas de Coca-cola o de Kas, electrodomésticos en los que claramente se ve la marca del producto como la de la cafetera industrial Gaggia o marcas de ropa como el pantalón Lois (fig. 6). Todo esto demuestra cómo se entendía la fotonovela como un medio de gran alcance y capacidad de persuasión entre un público consumidor concebido como "femenino" y a qué contextos se vinculaba la inserción en España de marcas y productos del extranjero.

En el primer número de la colección Corín Tellado "Soy un soltero feliz" ya encontramos la reproducción de este modelo. Esta fotonovela está protagonizada por Esther Riera, una de las actrices más populares del elenco de Rollán. En 1969 llegó incluso a protagonizar una película anunciada por la editorial y producida por Warner Bros ${ }^{37}$. El argumento se organiza a través de la tensión amorosa existente entre

34 Martín Gaite, 2000,p. 134.

35 El último cuplé (Juan de Orduña, 1957).

36 “Destrúyeme después," Corín Tellado 2, 1966.

37 Esto se promociona dentro de la colección Sayonara en "La primavera florida de "Tengo que abandonarte"”, Sayonara, 22 (1969), p. 3. 


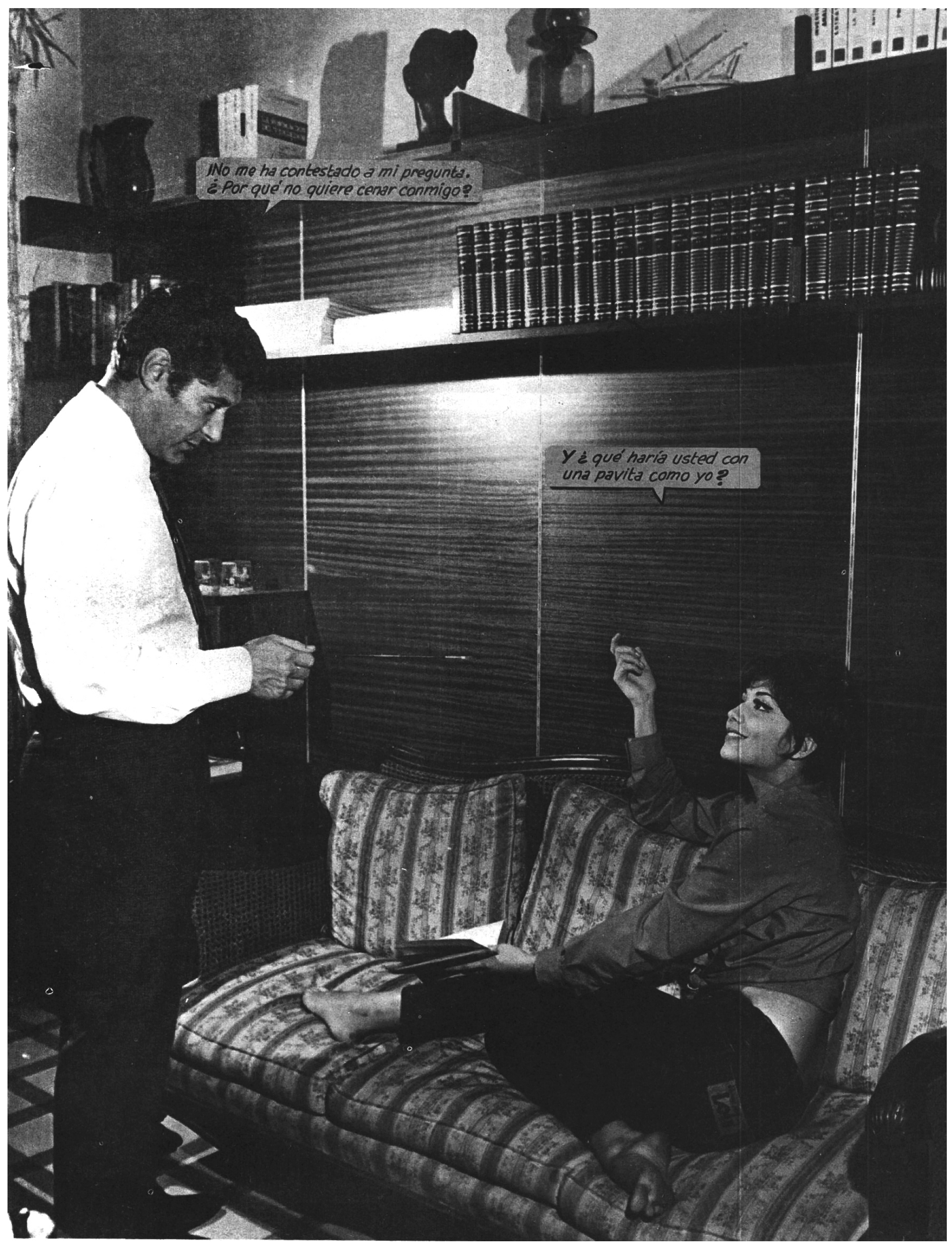

Fig. 6. "Soy un soltero feliz", Corín Tellado, 1 (1966), p. 20. 
Ahidee, una elegante e inteligente estudiante de derecho, y Boris, un enigmático pintor de éxito. Con el amor como centro y estructura de todo las fotonovelas de Corín Tellado muestran una construcción muy determinada de las relaciones afectivas en las que existe una idealización del amor romántico que se privilegia por encima de otras relaciones interpersonales. Ya en la primera página se nos presenta a una Ahidee despreocupada, sonriente, tumbada bocabajo en diagonal en la cama en pijama con un pie desnudo levantado y con la mano en la cabeza y mirando a la cámara que está sobrevolando a la protagonista, situando al lector en una posición de voyeur. Él, por el contrario, se encuentra mirando al frente. Está tapando a una mujer situada en segundo plano, sin mirarla, lo que obliga al lector a focalizar su atención en Ahidee situada en la imagen superior que también es de mayor tamaño. Esta mirada de la cámara es un ejemplo muy claro de los roles que establece Laura Mulvey al analizar la escopofilia masculina como una forma de estructurar la mirada que adjudica al hombre la satisfacción de mirar y a la mujer el placer de ser mirada ${ }^{38}$. La elección del fotógrafo de mirar a Esther Riera y esconder a la mujer que se encuentra en un segundo plano, oculta por el protagonista masculino, en la siguiente viñeta puede desentrañar las posibles identificaciones de las lectoras que podían proyectar en Ahidee su anhelo de ser objeto del deseo masculino frente a otras mujeres (fig. 7).

En las páginas consecutivas la vemos en una postura segura, con el dedo levantado y echada hacia adelante dispuesta a hablar con firmeza (fig. 8). Además, el contrapicado reafirma la sensación de seguridad y superioridad. En palabras del personaje: "No soy sensiblera, ni sentimental, ni enamoradiza... Estoy completamente segura de mí misma. Y satisfecha, además"39. Lo que podía parecer una alternativa a la pasividad asociada a los personajes femeninos se convierte en objeto de deseo del lector y del personaje masculino. La ausencia de él en el plano y la permanente visión del personaje femenino como objeto de contemplación exigen que la lectora adopte el punto de vista masculino. La cámara es tan solo una forma de recrear cómo se miran el uno al otro y, en concreto, del deseo de Boris hacía Ahidee. Por otro lado, el tipo de imágenes que formaban las viñetas, así como la composición de la página favorecían no sólo que la narración avanzara, como han hecho notar Juan Miguel Sánchez Vigil y María Olivera Zaldua ${ }^{40}$, sino también que las lectoras se pudieran recrear en los detalles tanto de los decorados como de maquillaje, vestuario y peluquería. En efecto, esto era facilitado por la elección de composiciones sencillas para maquetar las fotografías realizadas por Antonio Baños (responsable de fotografía en todos los números analizados aquí) de manera que cada página contenía habitualmente cuatro o seis viñetas que se combinaban con planos retrato y detalles.

En este devenir entre la lectora y Ahidee se desplaza la mirada y la lectora se balancea suavemente entre ser objeto de deseo y poseer la mirada. En sus estudios sobre Corín Tellado, Andrés Amorós nos indica que no se trata solamente de identificarse con estos personajes sino también de "participar imaginativamente en su vida" 41 . De este modo podemos determinar que en estos procesos la fotonovela de Corín Tellado permite que las lectoras puedan soñar momentáneamente con ser la protagonista principal que es objeto de atención y elección del género masculino. Esta erotización del empoderamiento de Ahidee no dura mucho. A medida que Ahidee se enamora del protagonista masculino, chocamos con una serie de contradicciones que resquebrajan la posible autonomía e independencia del personaje. Estas paradojas no se dan únicamente en Corín Tellado, sino que ya eran descritas por Mulvey en relación con películas como Sólo los ángeles tienen alas (1939) o en Tener o no tener (1944):

38 Laura Mulvey, "Visual Pleasure and Narrative Cinema" en Film Theory and Criticism: Introductory Readings, Leo Braudy

y Marshal Cohen (ed), New York, Oxford UP,1999, p. 837.

39 "Soy un soltero feliz", Corín Tellado, 1 (1966), p. 9.

40 Juan Miguel SÁnchez Vigil y María Olivera ZaLduA, "La fotografía en las fotonovelas españolas", Documentación de las Ciencias de la Información, vol. 35 (2012), p. 33, http://dx.doi.org/10.5209/rev_DCIN.2012.v35.4044.

41 Amorós, 1968, p. 71. 

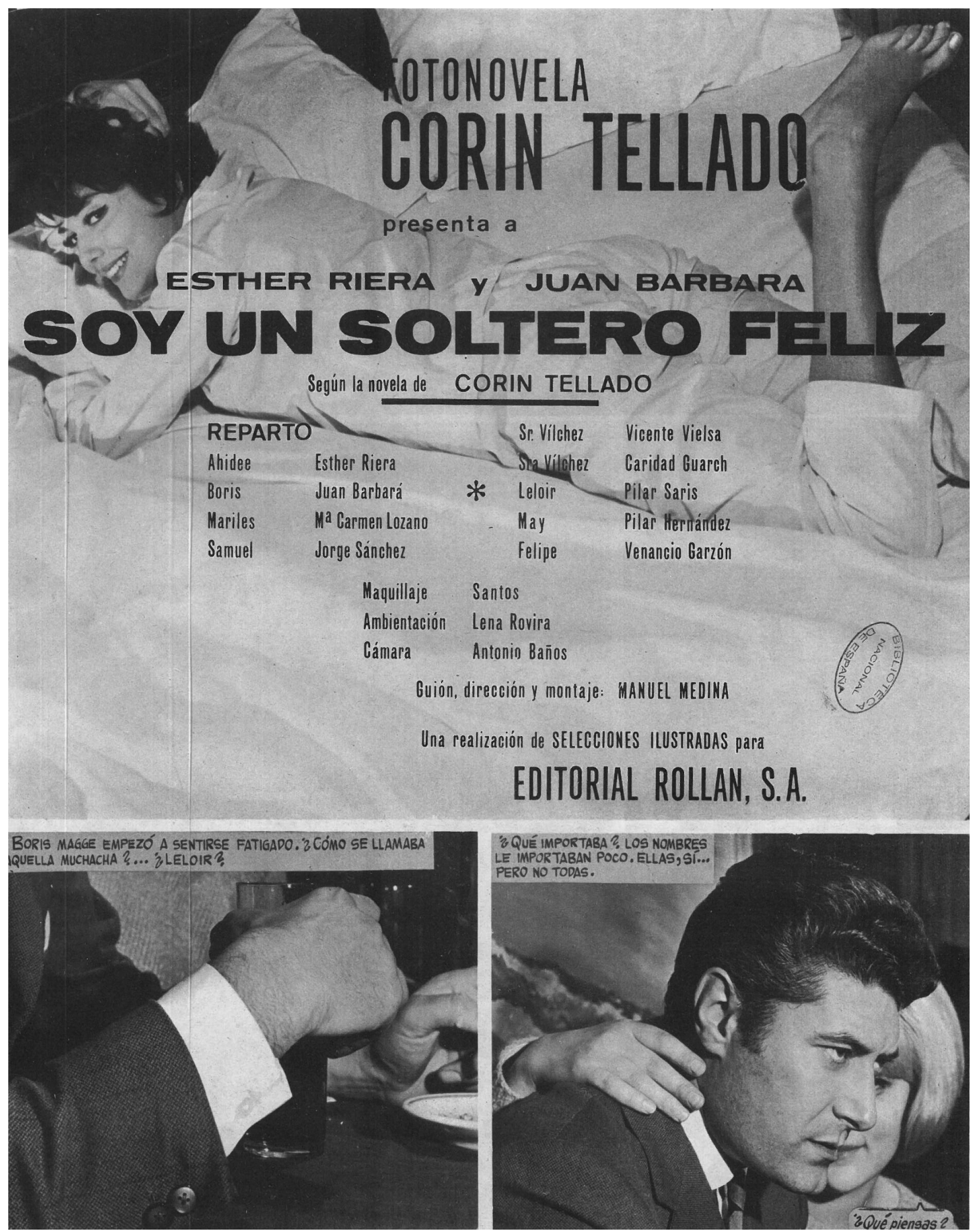

Fig. 7. "Soy un soltero feliz", Corín Tellado, 1 (1966), p. 3. 

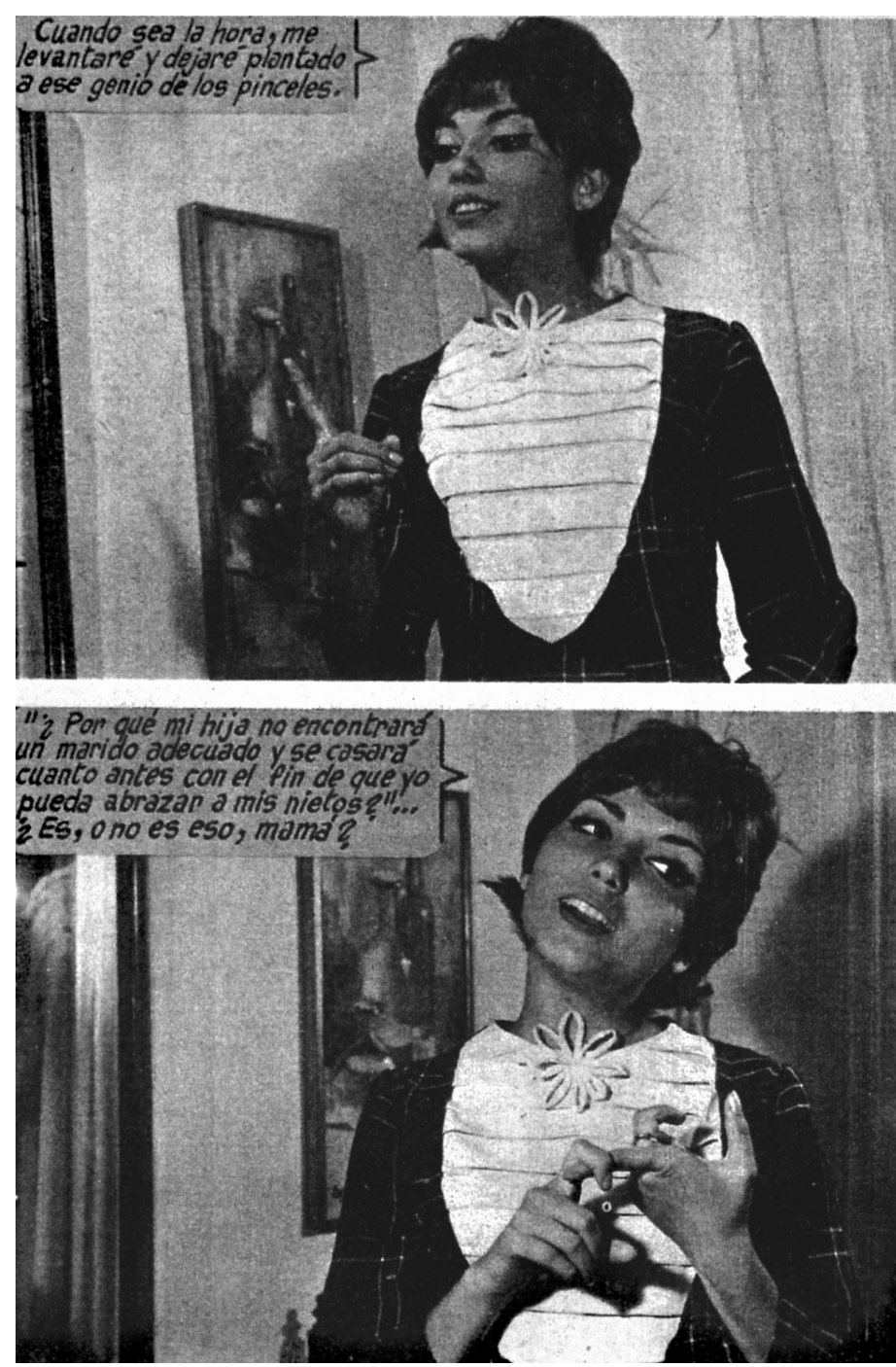

Fig. 8. "Soy un soltero feliz”, Corín Tellado, 1 (1966), p. 6.
La película comienza con la mujer siendo objeto de la combinación de miradas del espectador y de los protagonistas masculinos. Está aislada, glamurosa, expuesta, sexualizada. Pero a medida que la historia avanza y se enamora del protagonista principal masculino se convierte en su propiedad, perdiendo las características glamurosas exteriores, sus connotaciones de show-girl; su erotismo se sujetará únicamente a la estrella masculina ${ }^{42}$.

Con ciertas diferencias, esto lo podemos ver comparando estas viñetas iniciales de la fotonovela con otras posteriores. En ellas vemos a Boris obligando a Ahidee a quedarse junto a él de diversas maneras. Ante la influencia de Boris, Ahidee está vacilante. La postura de él la presiona a echarse hacia atrás, retratándola en esta vez con un plano picado (fig. 9). Con el mismo plano picado, vemos una escena que se repite a lo largo de los números: la de ella tumbada en la cama pensando en el protagonista masculino cuando se da cuenta de que está enamorada (fig. 10). Al fin y al cabo, esto no es extraño ya que era el mismo lugar, como ejemplifica con una mirada crítica Nuria Pompeia, donde soñaban y leían las jóvenes las revistas y libros de carácter amoroso de esa época (fig. 11).

A estas alturas del relato la protagonista tiene que demostrar que no es solo una chica con aires de independencia, sino que también cumple con una serie de valores y requisitos, en especial, no haber mantenido relaciones sexuales fuera del matrimonio. Todo esto solo es un ejemplo más de la dicotomía que existía entre la buena esposa y la que no servía para ello, pero esta vez, disimulado en un modelo del personaje femenino que se vende como contestatario frente a los viejos modelos. Visualmente esto aparece representado en el conjunto de viñetas donde se nos presenta al personaje de Adelaida en "Eres una pecadora" cuya ocupación es la prostitución (fig. 12). Podemos observar cómo se ha compuesto la maquetación para que podamos comparar al personaje principal, situado a la izquierda, con Adelaida. Frente a los aros grandes y vistosos y el moño de Adelaida, nos encontramos con la protagonista representada con solemnidad con un velo usado tradicionalmente para ir a misa, símbolo de la pureza. Asimismo, detrás de ella podemos ver una reproducción del cuadro de Miró Perro frente al sol (1949) que se adapta al retrato de Adelaida y que hace que fijemos la vista en ella. En cambio, en la parte inferior derecha, vemos a la protagonista

42 Mulvey, 1999, p. 840. 

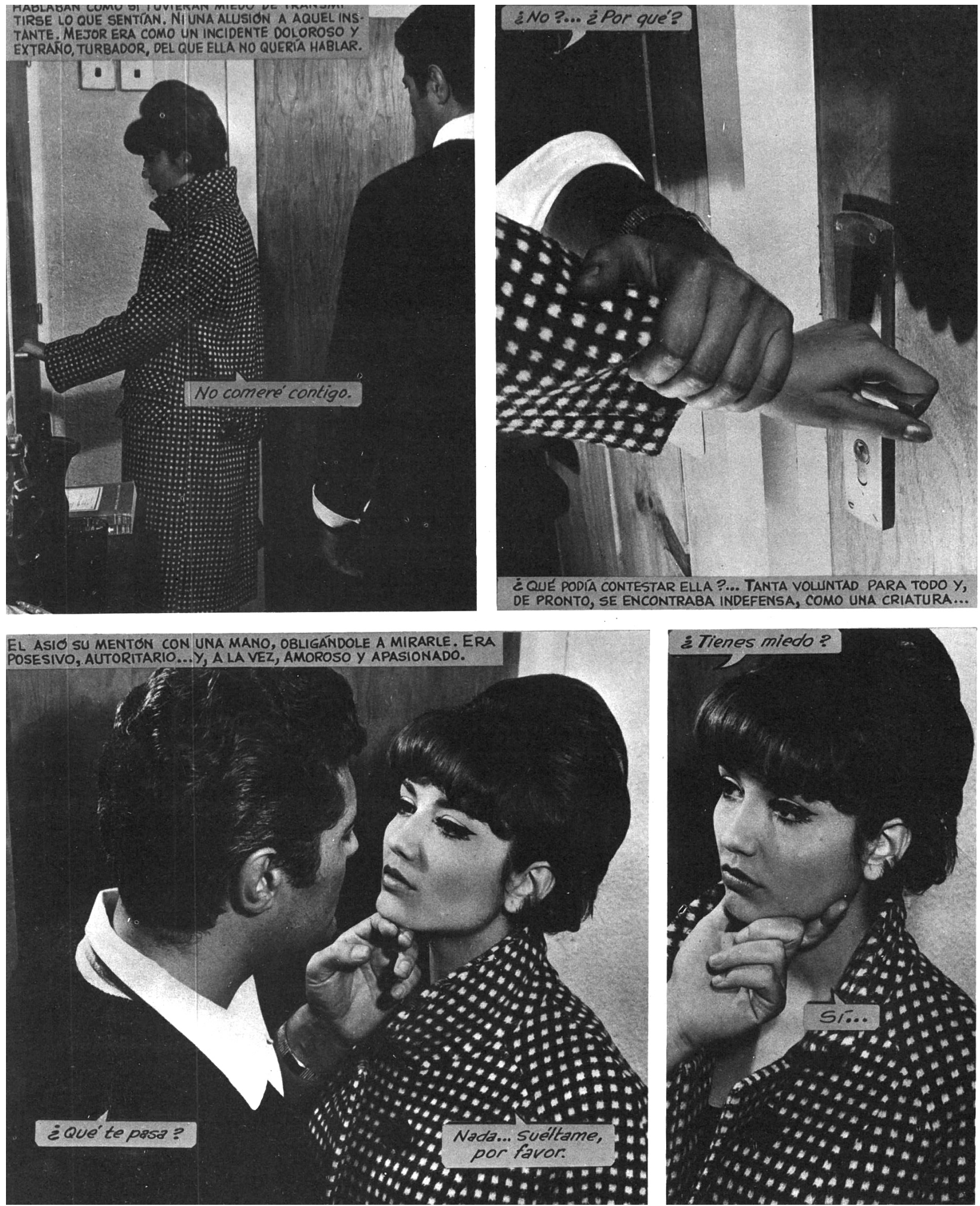

Fig. 9 "Soy un soltero feliz”, Corín Tellado, 1 (1966), p. 37. 


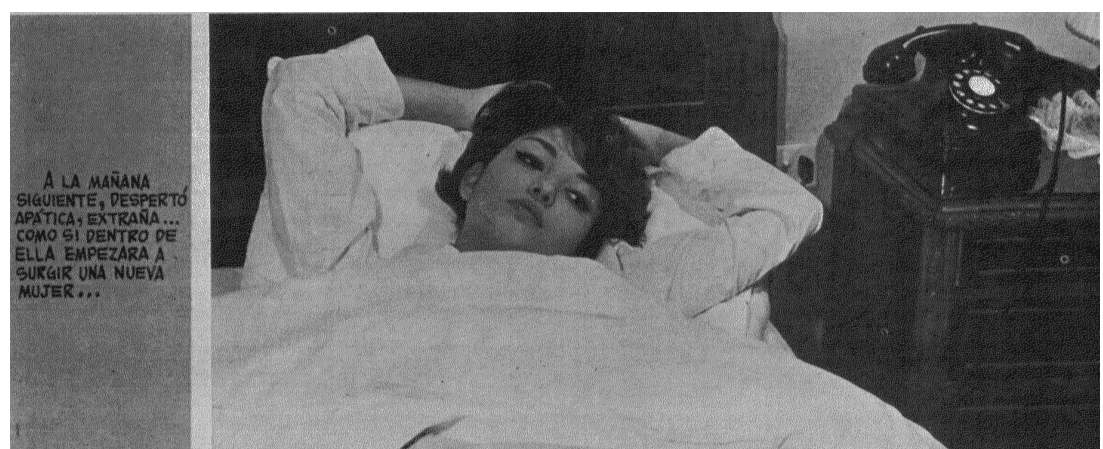

Fig. 10. "Soy un soltero feliz,” Corín Tellado, 1 (1966), p. 39.

principal fotografiada ante un retrato femenino cuya estética resulta mucho más convencional.

Este erotismo refinado tan destacado de Corín Tellado y que muchas veces se ha reconocido como un modo de subvertir los modelos de mujer durante el franquismo y como una forma de engañar al censor ${ }^{43}$ se convirtió en la fotonovela en un modo de estructurar el deseo a

\section{El matrimonio..}
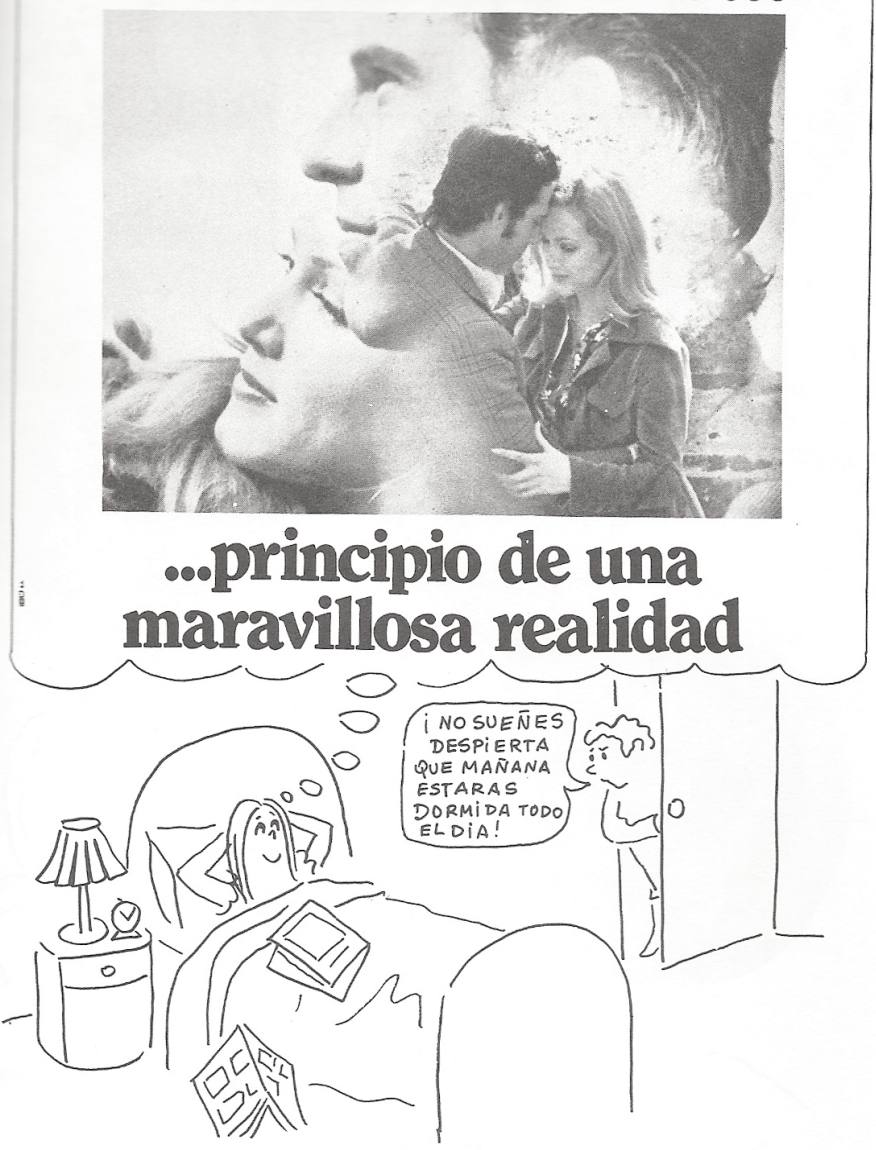

Fig. 11. Nuria Pompeia, Mujercitas, Barcelona, Punch Ediciones, 1975, p. 47. través de la cámara en una única dirección, para poder superar las barreras de la censura a través de la presentación de un erotismo basado en el amor romántico. Ejemplo de estas valoraciones, muy contrarias a las que se ven por parte de los académicos españoles en los años setenta, son las de Francisco Umbral en su Diccionario de Literatura donde reivindica la literatura de Corín Tellado y resalta la habilidad de la autora para "cuando el erotismo estaba prohibido, censurado, mi amiga Corín se inventa el erotismo del corazón (...), se inventa en la posguerra una fórmula literaria para burlar la censura: la novela de amor sin sexo, la novela de sexo sin sexo". Famosa es la calificación que le proporcionó el escritor cubano Guillermo Cabrera Infante en $O$ como una inocente pornógrafa en la que recalca la maestría de Corín Tellado con el Marqués de Sade o con Pauline Réage"44. No obstante, como hemos podido comprobar, este erotismo de Tellado se basó en un modelo de feminidad que no rebasaba más que superficialmente los ideales de abnegación femenina. En definitiva, aunque las representaciones de las protagonistas de clase alta al inicio de la fotonovela supusieron un contramodelo a los roles impuestos por el sistema patriarcal y seguramente tuvieron algún tipo

43 Ángeles Carmona GonzÁlez, "El amor en los tiempos de la censura”, en Corín Tellado. El erotismo rosa, Madrid, Espasa, 2002, pp. 93-102.

44 Francisco Umbral, "Letra T", en Diccionario de la Literatura, Barcelona, Planeta, 1995, p. 236; "Una inocente pornógrafa”, en $O$, Barcelona, Seix y Barral, 1975. Aparecen citados en: María Teresa GonzÁLEz, Corín Tellado. 60 años de novela de amor, Asturias, Consejería de cultura, comunicación social y turismo, 2007, pp. 56,53. 

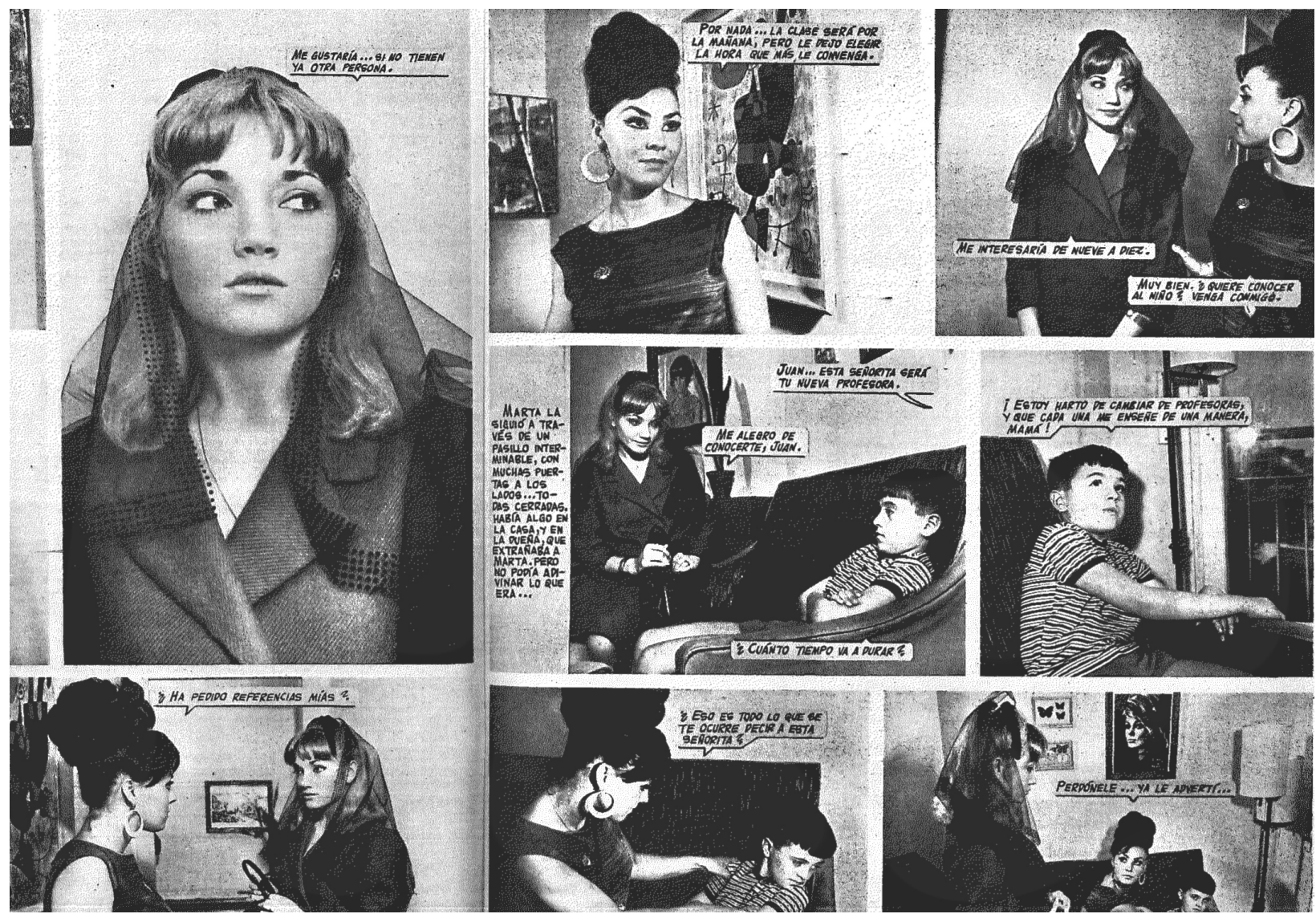

Fig. 12. "Eres una pecadora”, Corín Tellado, 11 (1966), p. 24.

de impacto en el imaginario de la sociedad española, construyeron la subjetividad femenina a través del placer de las lectoras de ser miradas y de valores reaccionarios, por lo que no abandonaron la idea de la feminidad como sinónimo de dependencia con respecto al género masculino. Como deja claro la propia Corín Tellado en uno de sus consultorios "el que te hayas divertido no es pecado" siempre y cuando esto no te "haya descentrado un poco respecto a tu verdadero carácter sentimental" 45 .

\section{Simplemente María. Un nuevo tipo de fotonovela}

En 1972 se inaugura un nuevo tipo de fotonovela con la publicación de Simplemente María por la editorial Sedmay. Esta fotonovela era una adaptación del serial radiofónico homónimo emitido entre 1971 y $1973^{46}$ por un conjunto de emisoras dependientes de la Secretaría general del Movimiento agrupadas bajo el nombre de Supercadena $72^{47}$. Esta radionovela y fotonovela es una adaptación de la novela de la escritora argentina Celia Alcántara, novela que ya se había producido en forma de telenovela en Perú con éxito en $1969^{48}$.

\footnotetext{
45 Corín Tellado, “Corín Tellado contesta a...”, Corín Tellado, 12 (1967), p. 2.

46 CAMPO, 1975, p. 19.

47 "Escuche todos los días...", Simplemente María, 14 (1972), p. 43.

48 Tere VAle, Valentín Pimstein: una vida de telenovela, Ciudad de México, Editorial Miguel Ángel Porrúa, 2016, p. 29.
} 
Al igual que otras fotonovelas de la época, como Lucecita o Esmeralda, el argumento de Simplemente María gira en torno a la vida de la protagonista principal: María, una joven que emigra del pueblo a Madrid en busca de una vida mejor y que pasa de trabajar como sirvienta en una casa a ser una reconocida modista en la ciudad. La colección de Simplemente María apostó por un personaje cercano a los problemas y la realidad de las lectoras. A diferencia de lo que ocurría en Corín Tellado, sí que existía una correlación entre el mundo de María y el de sus compradoras. Los responsables de la fotonovela se ayudaron de hechos reales de la coyuntura española de los setenta, como la emigración rural, para facilitar la identificación de la lectora con el relato y la aproximación a la realidad ${ }^{49}$. María representaba los problemas de las mujeres en España que se acababan de incorporar al mundo laboral en el desarrollo económico español. Esto se ejemplifica en las primeras páginas, cuando la propia colección advierte que María no es tan solo un personaje de ficción, sino que todos hemos conocido a una María Ramos o a una "MARIA simplemente"50.

A nuestro parecer, Simplemente María es un buen punto de partida para los debates realizados desde la teoría fílmica feminista sobre la necesidad de identificación del espectador con los personajes de la película. Tal y como establece De Lauretis la industria cinematográfica se basa en agradar a los espectadores por razones puramente comerciales para lo cual es necesaria la "implicación de la subjetividad del espectador y la posibilidad de identificación. A la vez que estas prácticas identificadoras ganan consumidores, construyen el género" 51 . Ejemplo de esto son las distintas adaptaciones que se hicieron de la novela original, como la de este caso de estudio o su versión peruana en la que la protagonista llega a Lima del mismo modo que María a Madrid, adaptándose así a la cotidianeidad de sus compradoras. Este acercamiento a las lectoras se reflejó también en el uso del lenguaje en el que se evitan las frases grandilocuentes y se apuesta por un lenguaje sencillo que corresponde con los conflictos vitales de las lectoras.

Por otro lado, la fotonovela abandonó el formato de la "fotonovela completa" para mantener la estructura del serial radiofónico de modo que la colección se dividió en fascículos coleccionables que iban desarrollando el mismo argumento y personajes. De este modo, la publicación por entregas actuaba como medida disuasoria de que los números de la colección se comprasen de forma intermitente y aumentó la posibilidad de fidelizar a las compradoras. Esta vez, los personajes no desaparecían al acabar cada fascículo, sino que convivían con las lectoras a lo largo del desarrollo de toda la colección lo que facilitó la cotidianeidad y permitió relaciones y procesos más profundos ${ }^{52}$. Las posturas, gestos y lenguaje de los personajes son más espontáneos que en el anterior caso de estudio. Las emociones son representadas con gran intensidad y teatralización, lo que las acerca de nuevo a la realidad y facilita la lectura por parte de las compradoras. No obstante, Simplemente María creó simultáneamente un universo enrevesado -lo cual claramente va en la línea de la telenovela que se estaba empezando a popularizar en América Latina y que, como cabe recordar, ya se había producido una adaptación de esta novela en ese género lleno de elementos inverosímiles y fantasiosos: curaciones milagrosas, atropellos de coches, encarcelamientos falsos, muertes inesperadas... En definitiva, Simplemente María consiguió crear un producto complejo en el que las lectoras podían identificarse con la protagonista y soñar a la vez con una vida más emocionante.

Simplemente María es también de gran relevancia para analizar cómo funcionó en España el star-system y la creación desde la industria cultural de ídolos mediáticos. La editorial Sedmay articuló la colección a través de la voz del personaje de María y creó una ficción en la cual era el personaje principal quien se dirigía a sus lectoras directamente, contestando a dudas e inquietudes que le planteaban en las cartas o animando a concursos como el de "Pase un día con María" en el que se sorteaba conocer a la actriz protagonista o en el que se regalaba la supuesta máquina de coser que utilizaba María. Del mismo modo, el serial

\footnotetext{
49 Pedro Sempere, Semiología del infortunio: lenguaje e ideología en la fotonovela, Madrid, Felmar, 1976, p. 38.

50 "Sin más equipaje que una simple maleta...", Simplemente María, 1 (1972), pp. 2-3.

51 Teresa de Lauretis, Alicia ya no. Feminismo, Semiótica, Cine, Madrid, Ediciones Cátedra, 2002, p. 216.

52 SEMPERE, 1976, p. 37.
} 

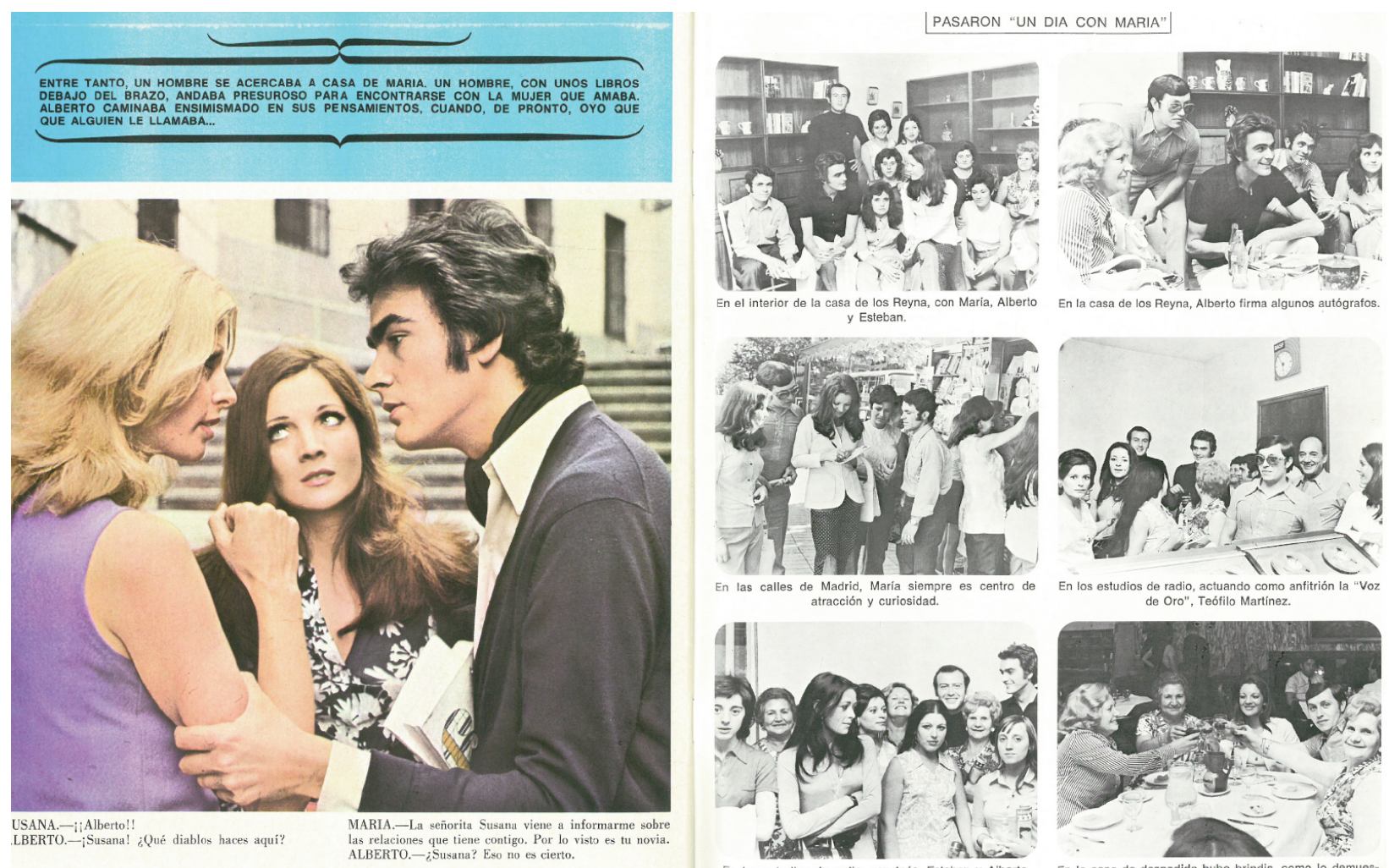

(CONTINUARA.)
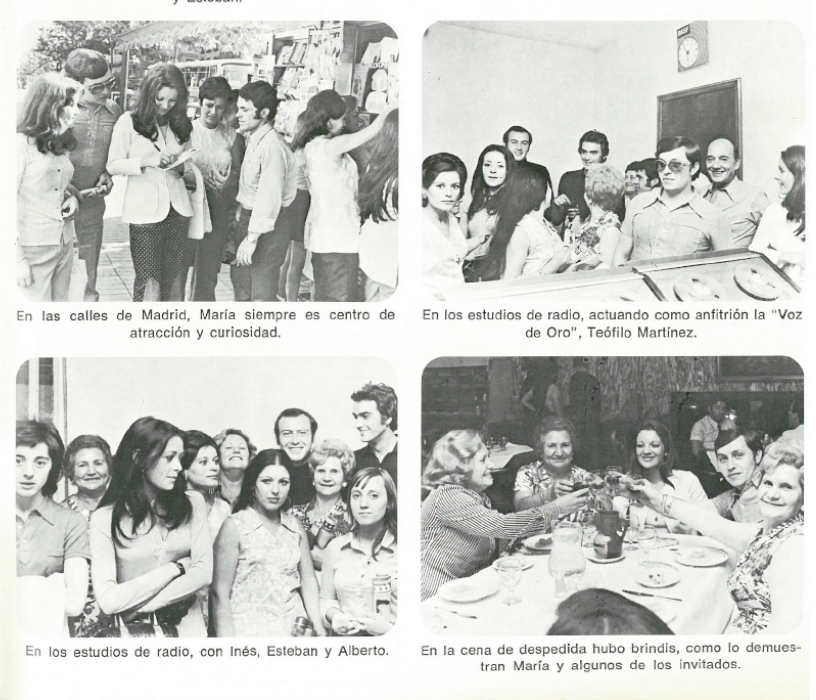

Fig. 13. "Pasaron 'Un día con María”, Simplemente María, 9 (1972), p. 9.

radiofónico creó la sección "Minutos de María" en la que Marisol Martínez dedicaba un rato a hablar de temas como consejos para el hogar, decoración o la familia ${ }^{53}$. No hay duda de que María llegó a tener mucha atención y fama entre las lectoras como muestran las fotografías de "Pase un día con María", donde se ve a las ganadoras emocionadas en una de las casas de los protagonistas o a María en la calle firmando autógrafos rodeada de personas (fig. 13). Significativo es también el hecho de que se creó un club de fans al poco de empezar a publicarse la fotonovela ${ }^{54}$.

La simultaneidad en la radio y en la fotonovela del personaje de María fue una eficaz estrategia para compensar las carencias de cada uno de estos medios. El serial radiofónico, de una hora de duración, se emitió diariamente a las 16:30 y era interpretado por Marisol Martínez. Por el contrario, la fotonovela era publicada semanalmente y era protagonizada por María Salerno. Es importante establecer que los dos productos convivieron durante un año, lo que complica la relación que podrían tener las lectoras que accediesen a ambos. En las fuentes estudiadas para esta investigación se ha detectado cierta confusión en los medios de comunicación del momento respecto a estas dos actrices y no se ha podido determinar con certeza si Marisol Martínez - de la cual no hay más rastro que las entrevistas que se le hicieron en la época-era un seudónimo de María Salerno o se trató de dos personas diferentes. Además, en la ficha técnica de la fotonovela aparecen los nombres de los actores que interpretan todos los personajes excepto en el caso de María en el que solo podemos encontrar "María... Simplemente". En la entrevista de 1973 a Marisol Martínez en el periódico $A B C$, aparecen fotografías de la actriz de la fotonovela por lo

\footnotetext{
53 CAMPO, 1975, p. 139.

54 "Club 'MARÍA"” Simplemente María, 35 (1972), p. 2.
} 


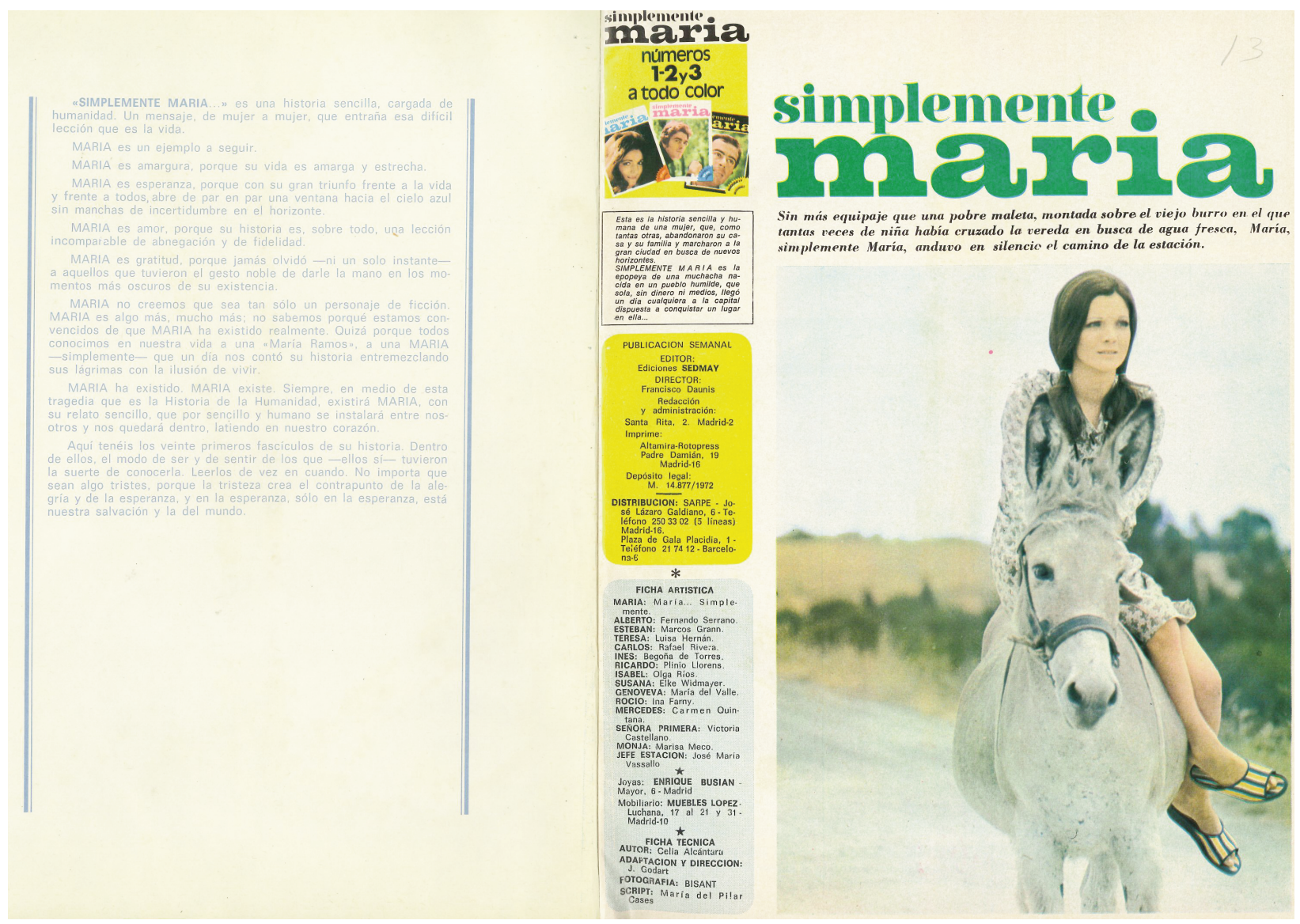

Fig. 14. "Sin más equipaje que una simple maleta...", Simplemente María, 1 (1972), pp. 2-3.

que, de no tratarse de la misma intérprete, parece clara la intención de ligar la cara de María Salerno a la voz del serial radiofónico ${ }^{55}$.

Como ya se ha adelantado, el argumento de esta colección gira en torno a la vida de María Ramos, una joven que emigra desde el medio rural a Madrid. Una vez allí consigue trabajo en una casa como sirvienta. En este trabajo conocerá a uno de los personajes principales: Teresa que trabaja en la casa de enfrente y de quien se hace amiga enseguida. María, en una de sus salidas con Teresa, conoce a Alberto Reyna, un estudiante de medicina de buena familia de quien se enamora y termina quedando embarazada. Los primeros fascículos de la fotonovela (del 1 al 20) transcurren entre las idas y venidas de la relación de María y Alberto quien le promete casarse con ella al terminar la carrera. Sin embargo, Alberto incumple su promesa y se casa con Angélica que morirá poco después debido a una complicada operación a la que se somete para poder dar un hijo a Alberto. María decide casarse con Esteban, el maestro del barrio donde viven que representa la ayuda y dedicación que María ha necesitado para ascender.

A partir del fascículo número veinte, Simplemente María transcurre entre dos polos. El primero, el ascenso de clase de María, quien termina teniendo una red de tiendas de moda cumpliendo con las aspiraciones de sus lectoras y alimentando la necesidad de insertarse en la cultura del consumo. Esto tiene un impacto en las representaciones de María cuyo ascenso de clase se hace patente a través del vestuario o el peinado. En la imagen en la que se nos presenta a María aparece montada en un "viejo burro" y no parece

55 Meseguer, 1973, pp. 216-219. 

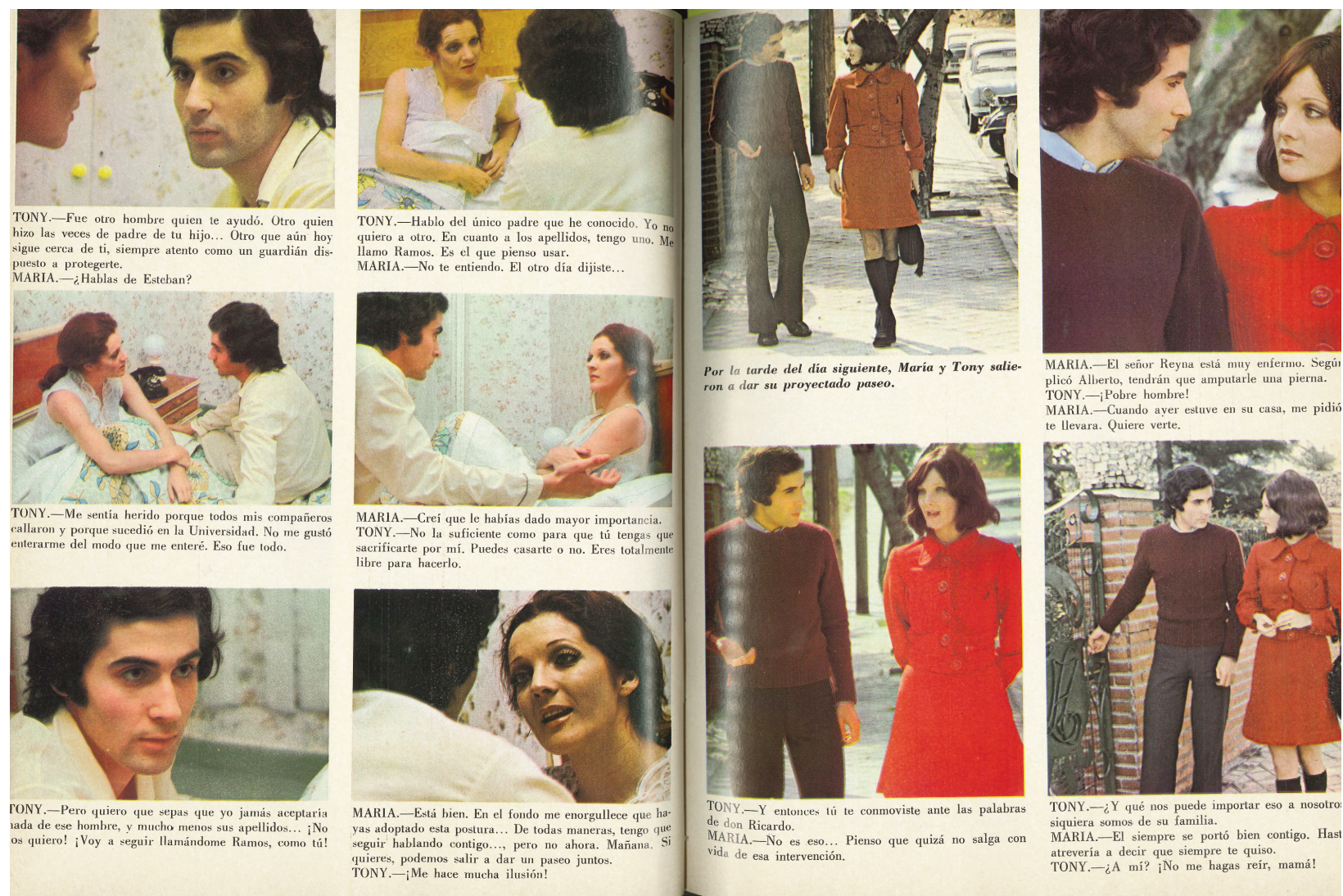

Fig. 15. "Ita, después de la última conversación...," Simplemente María, 29 (1972), pp.10-11.

tener equipaje, aunque en el texto que la acompaña se precisa que no lleva más equipaje que "una pobre maleta" 56 . Lleva un vestido gris, de tela fina y unas zapatillas de chanclas a rallas y es que, como nos indican las palabras de la siguiente página, al llegar a Madrid María iba "pobremente vestida"57 (fig. 14). E1 pelo natural, largo y liso de los primeros números se sustituye más adelante por una peluca de pelo corto y rizado, por elaborados recogidos o medias melenas que la acercan a los modelos que hemos visto ya en los personajes de clase alta de Corín Tellado. Del mismo modo, María cambia los vestidos sencillos de colores grises o pasteles de los números iniciales por vestidos de manufactura más complicada, de colores vistosos como el naranja o el rojo y con elementos como los cuellos de piel o estolas, a medida que avanza la fotonovela (fig. 15). Este cambio visual entre la María sencilla y humilde de los primeros números con la que claramente las lectoras se podían sentir identificadas y la María que se va aproximando al estereotipo de lo que las lectoras podían reconocer como clase alta facilitaría la creencia de que, con esfuerzo y trabajo, eso también podía pasarles a las lectoras. Al mismo tiempo, Simplemente María creó una red de consumo que no se limitó a la fotonovela o al serial radiofónico. María vendía todo tipo de objetos: un disco de Simplemente María con canciones que se incluían en el serial radiofónico, un medallón que decía ser una copia del que le regaló Esteban a María, jerséis con el nombre de María, joyas que decían estar diseñadas por la protagonista o las cubiertas de tapa dura azules con letras doradas en el lomo para coleccionar, encuadernar y guardar cuidadosamente los fascículos divididos en cuatro tomos ${ }^{58}$.

\footnotetext{
56 “Sin más equipaje que una simple maleta...", Simplemente María, 1 (1972), p. 3.

57 “Sin más equipaje que una simple maleta...", Simplemente María, 1 (1972), p. 4.

58 CAMPO, 1975, pp. 97-99.
} 


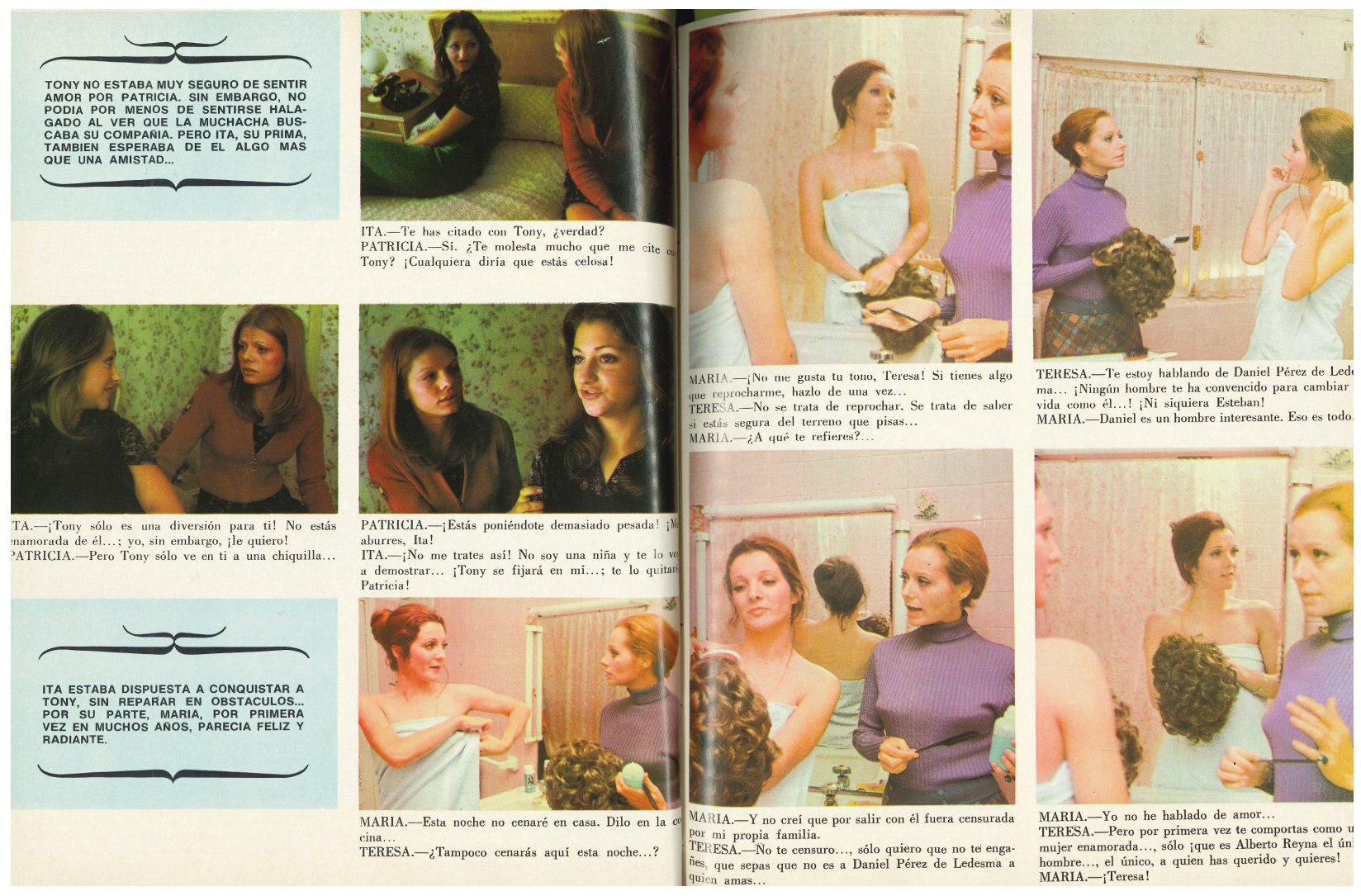

Fig. 16. “Sin más equipaje que una simple maleta...”, Simplemente María, 1 (1972), pp. 10-11.

El segundo de los polos que vertebran la fotonovela es la lucha de María por su hijo. La retórica de la buena y sacrificada madre atravesará toda la fotonovela construyendo la identidad de María. De hecho, a diferencia de lo que pasa en Corín Tellado, en la cual la estructura del relato empieza y acaba con una historia de amor, Simplemente María comienza con la concepción de su hijo y termina con la boda de este. Por otra parte, merece la pena detenerse en analizar cómo se representa el parto de su hijo. Ese momento se representa con un plano de la cara de ella tumbada vista desde arriba, maquillada, y con el pelo suelto (fig. 16). Está con la boca medio abierta y los ojos entreabiertos con una expresión ambigua, entre el placer y el dolor, como nos indica también el texto que la acompaña: "El gran momento ha llegado. María, en medio de su infinito dolor, siente la gran felicidad de ser madre" 59 . Frente a esta visión idealizada del momento del parto encontramos especialmente relevante la respuesta que da Nuria Pompeia a esta problemática en 1967 en Maternasis donde relata mediante dibujos el transcurso del embarazo y deconstruye la idea de la maternidad como algo fácil y de completa felicidad para la mujer. Para entender la plena satisfacción de la maternidad que vende Simplemente María es interesante la comparación que se puede hacer entre el momento en el que le entregan el niño a María en el hospital y la última página de esta publicación de Nuria Pompeia. Mientras que Nuria Pompeia muestra la inseguridad del personaje cuando ve al niño llorar, a María no parece importarle nada más que el entusiasmo que le produce ver a su hijo por primera vez (figs. 17 y 18).

No obstante, hay que destacar que en Simplemente María sí que existe una subversión de la mujer supeditada al ámbito doméstico y, por lo tanto, consideramos que sí supuso una alternativa al rol tradi-

59 “Ita, después de la última conversación...”, Simplemente María, 29 (1972), p. 11. 


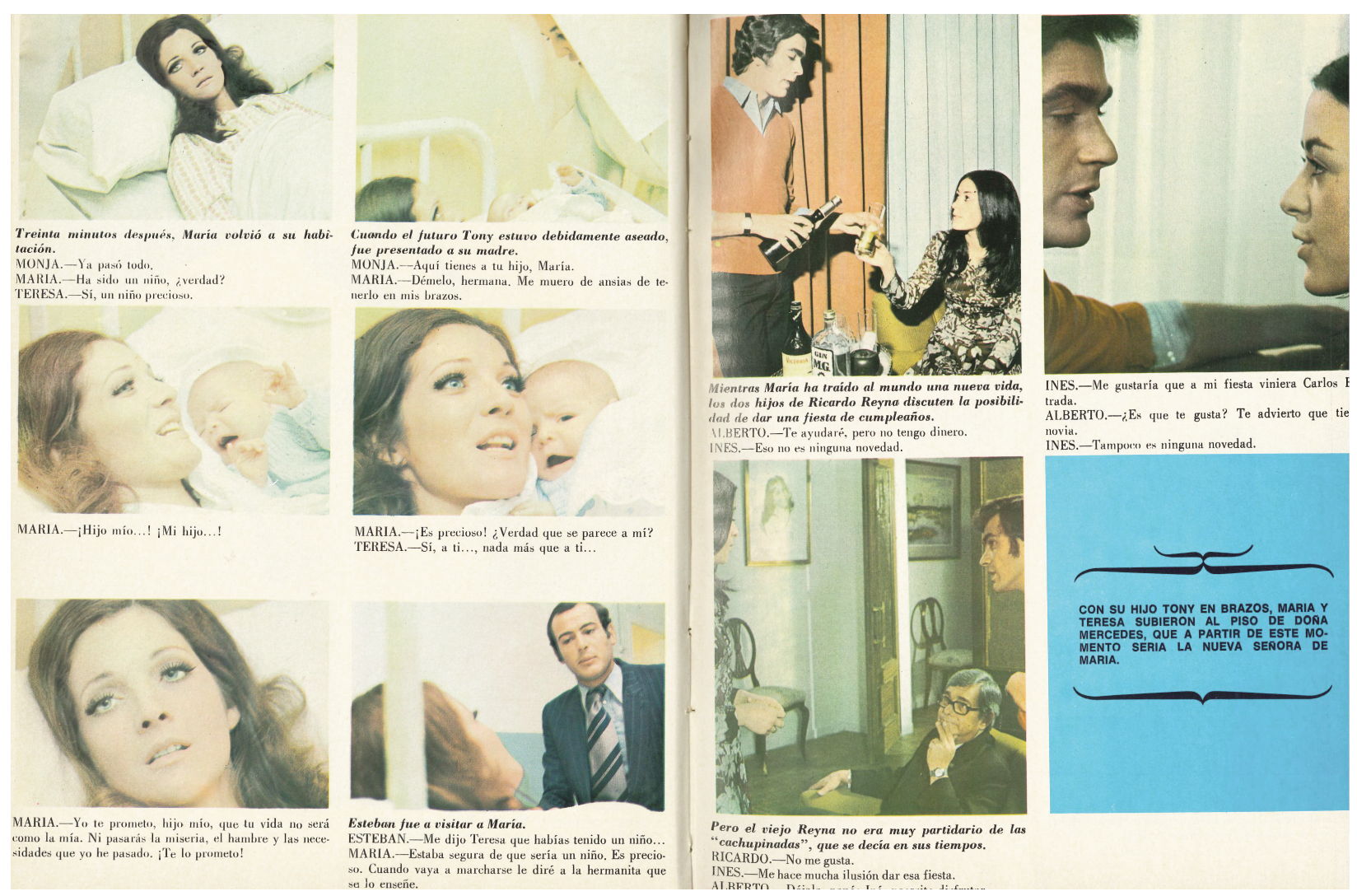

Fig. 17. María con su hijo, detalle de “Sin más equipaje que una simple maleta...”, Simplemente María 1, (1972), pp. 10-11.

cional de la mujer. Tal y como reconoce Pedro Sempere, en comparación con Lucecita el otro gran serial y fotonovela de los años setenta, Simplemente María "sorprendió el progresismo inédito en el género melodramático"60. A nuestro parecer esto se puede deber a varias causas: primero, a diferencia de lo que ocurre en las historias de la colección Corín Tellado, ella asciende de clase social a través de su trabajo, no del matrimonio. Aunque es problemático desde conceptos como la alienación o el ascenso de clase, Simplemente María introdujo la idea de que una mujer podía mantenerse por sí sola. A pesar de casarse con Esteban, María no tiene una dependencia ni emocional ni económica de ningún protagonista masculino, por lo que Simplemente María introduce la posibilidad en el imaginario de la sociedad tardofranquista de que una mujer pudiese salir adelante de forma independiente. Además, tiene a su hijo fuera del matrimonio lo que también supone un cambio respecto a la colección Corín Tellado donde todas las relaciones se daban dentro del ámbito legal y sagrado del matrimonio. Por último, en los primeros números María mantiene una buena relación de amistad con Angélica, la esposa de Alberto. Esta relación supone una variación entre los modelos de confrontación de la protagonista y la esposa del protagonista masculino y desobedece a la mirada androcéntrica de enemistad entre mujeres por la atención del protagonista masculino.

Sin embargo, a nuestro juicio, Simplemente María se quedó a medio camino. A pesar de que María consigue salir adelante sola, esto tan solo se le reconoce como mérito por haber sacado a su hijo adelante. Es decir, en realidad no se abandonan completamente los ideales de madre sacrificada ni se subvierten los roles tradicionales femeninos. A través de los expedientes de consulta voluntaria de esta fotonovela conservados en

60 Sempere, 1976, p. 83. 


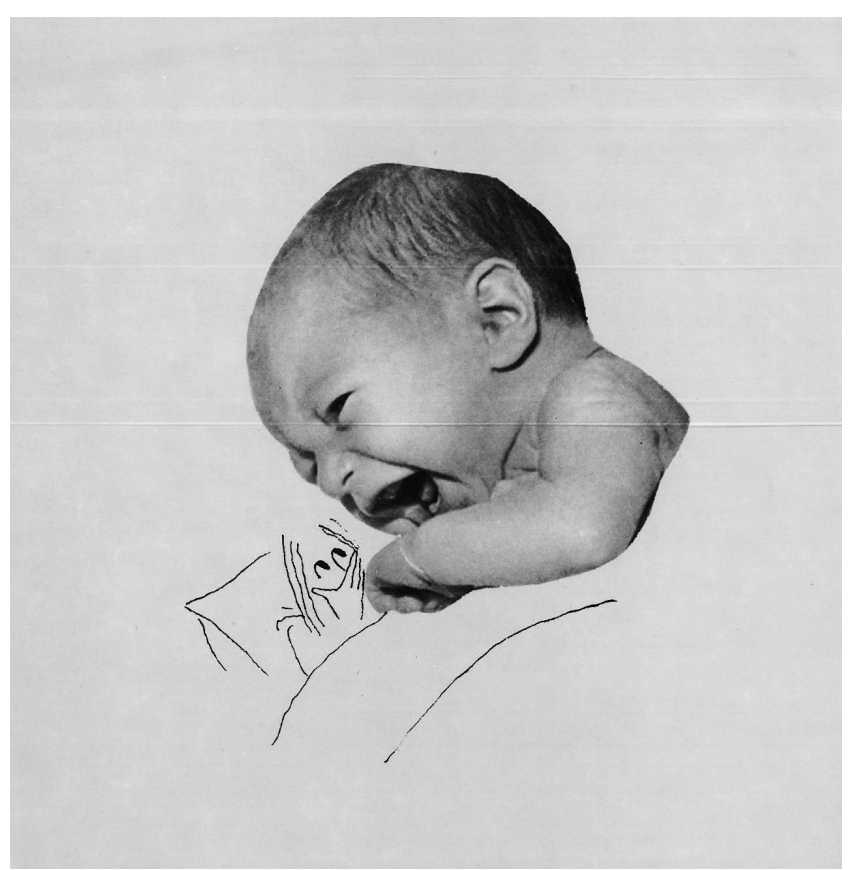

Fig. 18. Nuria Pompeia, Maternasis, Barcelona, Kairós, 1967, p. 88. el Archivo General de la Administración podemos hacernos una idea de cómo interpretaron todo esto las autoridades del régimen:

Una chica pueblerina marcha a servir a la gran ciudad. En contacto con ella, conoce a un joven estudiante de rica familia que la enamora. Ella espera un hijo; el estudiante rehúsa admitir su paternidad ante la diferencia social que los separa. María, la protagonista, quiere tener a su hijo, y está dispuesta a luchar sola, por él...

Fotonovela para inspirar compasión en la clase de público inmaduro amante de este género. Cabe destacar la fortaleza de la protagonista ante el infortunio y el cinismo de su seductor ante su incalificable acto, aprovechándose de la sinceridad de ella. $(. . .)^{61}$

Como vemos, los censores resaltan el sacrificio, lucha y fortaleza de María que se inserta así dentro de la retórica de la madre sacrificada. Del mismo modo, María no es en el momento responsable de sus actos a causa de su bondad y sinceridad; cualidades que justifican las relaciones fuera del matrimonio. Por otro lado, en la fotonovela no encontramos ninguna alusión a las relaciones sexuales entre María y Alberto hasta que María le comunica su embarazo. Esto se debe a que, como hemos podido observar en la documentación, la censura obligó a eliminar las pocas menciones que se hacían sobre este tema en la fotonovela. Además, de la lectura de estos documentos podemos concluir que existe entre sus autores una preocupación por eliminar descripciones o menciones a las relaciones sexuales que sean demasiado explícitas y que, por tanto, "puedan alterar la incipiente volición de las lectoras jóvenes"; en este mismo sentido se podría interpretar su interés por evitar fotografías que resultasen "inadecuadas" como, por ejemplo, los besos de los protagonistas ${ }^{62}$. Todo ello, refrenda el interés que reviste el análisis de las imágenes de la fotonovela para poder entender los imaginarios de género que podían visibilizarse en los medios en el tardofranquismo. En el caso concreto de Simplemente María, esto motivó que las representaciones del cuerpo, la sexualidad y el deseo de María quedaran prácticamente restringidos y supeditados a la maternidad entendida en un sentido muy convencional.

Tal y como advierte Manuel J. Campo, Simplemente María se edita en una época en la que las madres solteras son una realidad ${ }^{63}$. Por ello, dentro de este complicado contexto, no tendría sentido pensar que Simplemente María introdujo en el imaginario de las mujeres de la época la posibilidad de tener un hijo sin la necesidad de casarse, sino que se podría considerar como una propuesta acerca de cómo construir la identidad de las madres solteras (que ya existían) de un modo tolerable en la época. Esto pasa por hacerlo alrededor de valores que son aceptables dentro de la ideología del régimen franquista y el Movimiento a

61 Expediente de consulta voluntaria de Simplemente María del 24 de mayo de 1972. Expediente nº6405-72. Ministerio de Información y Turismo. Archivo General de la Administración. (03) 050.000- caja 73/01985.

62 Expediente de consulta voluntaria de Simplemente María del 24 de mayo de 1972. Expediente n ${ }^{\circ} 6405-72$. Ministerio de Información y Turismo. Archivo General de la Administración. (03) 050.000- caja 73/01985.

63 CAMPO, 1975, p. 13. 
quien pertenecían, conviene no olvidarlo, las cadenas donde se emitía el serial radiofónico Simplemente María. Esto no le quita valor a las ideas de emancipación de la mujer que plantea la fotonovela, pero nos sirve para entender el complicado momento que se estaba viviendo en los años setenta y la complejidad que supone la cuestión de la emancipación de la mujer en este tipo de publicaciones.

\section{Conclusiones}

Como ocurre con otros muchos productos culturales "femeninos" en esos años, la fotonovela se expande en un momento complejo en el que, a diferencia del anterior periodo de aislamiento internacional, las mujeres están adquiriendo cierta capacidad de agencia gracias a su creciente inserción en el mundo laboral y en la sociedad de consumo. En este contexto, en el que tuvieron un papel determinante tanto las políticas, ideales y valores de la apertura como los intereses concretos de empresas como las editoriales, insertas en dinámicas que trascendían las fronteras del país, la fotonovela fue uno de los medios a través de los que se construyeron los imaginarios, estereotipos y modelos de feminidad a finales de los años sesenta y en los años setenta.

La fotonovela tiene relevancia por ser parte de los intereses y motivaciones de las mujeres en los años del tardofranquismo. El objetivo de este estudio no era, por lo tanto, criticar la calidad del propio medio ni ridiculizar estos intereses. Sin embargo, sí se ha buscado problematizar las construcciones de la subjetividad femenina durante estos años. Es interesante al realizar nuestras conclusiones recuperar el concepto de tecnología de género, en la que, a través de la idea de tecnología de Foucault, Teresa de Lauretis, localiza ciertas tecnologías sociales, como la industria cinematográfica, que construyen el género ${ }^{64}$. De esta manera, cabe establecer cómo la fotonovela actuó de la misma manera, como una compleja tecnología de género que construyó una idea determinada de feminidad ligada a las ideas de modernidad y progreso y que problematizaron la emancipación de la mujer en esos años. Como hemos visto, es posible encontrar cierta subversión de los roles tradicionales en los modelos femeninos propuestos en Corín Tellado. No obstante, fue más bien una complicada tecnología de género que representó y construyó las paradojas que suponían todos los nuevos modelos de feminidad llegados del extranjero que, además, en el caso concreto de España, estaban atravesados por la ideología y agencia del régimen franquista. Del mismo modo, Simplemente María construyó la identidad de las madres solteras conjugando valores progresistas y reaccionarios al mismo tiempo. Por tanto, podemos determinar tras analizar los casos de estudio que esta construcción de la feminidad y de la emancipación de la mujer está llena de paradojas y contradicciones.

Tanto posicionándose a favor como en contra, muchos autores han ignorado esas contradicciones existentes en las novelas rosas y fotonovelas. Por un lado, Andrés Amorós, Juan Antonio Ramírez o Virginia Erhart han considerado la fotonovela como un modo de alienar a la masa de población femenina ${ }^{65}$. Por otro, autores como Guillermo Cabrera Infante, Francisco Umbral y Ángeles Carmona sobre Corín Tellado o Pedro Sempere sobre Simplemente María omitían las posibles contradicciones que presentaban los personajes femeninos dentro de estas obras ${ }^{66}$. Más compleja es la visión ofrecida por la autora Alicia. G. Andreu la cual relaciona la obra y la narrativa de la autora Corín Tellado con una lógica posmoderna. Aunque tal y como ella misma reconoce no todos los críticos estarían de acuerdo con la fecha que ella pro-

\footnotetext{
64 Teresa DE LAURetis, "La tecnología del género", Revista Mora, 2, trad. Ana María Bach y Margarita Roulet (1996), [en línea], http://genero.institutos.filo.uba.ar/sites/genero.institutos.filo.uba.ar/files/revistas/adjuntos/Mora2.pdf [Consulta: 1 de noviembre de 2018].

65 AMORÓS, 1974, y AMORÓS, 1968; RAMÍREZ, 1975. ERHART, 1973.

66 Carmona González, 2002; Francisco Umbral, "Letra T", en Diccionario de la Literatura, Barcelona, Planeta, 1995, p. 236; "Una inocente pornógrafa", en $O$, Barcelona, Seix y Barral, 1975. Aparecen citados en: GonZÁLEZ, 2007, pp.56,53; SEMPERE, 1976, p. 83.
} 
pone para situar el inicio de la posmodernidad con la narrativa de Tellado, existe relación entre varios elementos de esta y la posmodernidad, en línea con una lógica capitalista y consumista. De este modo: "su narrativa se distingue por una multiplicidad de discursos razón por la cual la ideología consumista viene acompañada de elementos de ambigüedad, contradicción y paradoja" ${ }^{67}$. Del mismo modo, Aurora Morcillo en sus interpretaciones sobre el cuerpo político de la mujer en el franquismo en los cuales analiza el Régimen en relación con el concepto de neobarroco y su lógica posmoderna establece cómo, a partir de la época de los años cincuenta y sesenta, "asistimos a una pérdida de integridad y unidad que da paso a una multidimensionalidad inestable"68. Dadas estas consideraciones sobre la época que nos ocupa y quedando demostrado que la fotonovela formó parte de esta lógica en la que confluyen diversos discursos y aparentes contrasentidos, resultaría simplista preguntarse si hubo una subversión al sistema patriarcal en alguna de estas colecciones sin haber analizado en profundidad todas estas paradojas que son el objeto de interés del artículo presente. Para nosotros, entender cómo se forma una de las primeras imágenes de la emancipación de la mujer desde la industria cultural llena de ideas contrapuestas, es un buen punto de partida para comprender cómo se construye actualmente la subjetividad femenina en el capitalismo tardío.

En el caso concreto de la fotonovela y a modo de conclusión, tras analizar en profundidad ambas colecciones consideramos justificado afirmar que, a nuestro parecer, aunque podemos encontrar elementos que desde un enfoque crítico feminista contribuyan a subvertir los roles tradicionales, ninguna de ellas supuso una verdadera alternativa al sistema patriarcal. De hecho, creemos conveniente apuntar que fueron dos tecnologías de género que renovaron este sistema en un momento en el que los cambios contextuales impedían que los viejos modelos pudiesen perpetuarse. Es decir, Corín Tellado y Simplemente María son un buen ejemplo de cómo se actualizaron los modelos de mujer dentro de las lógicas del patriarcado de modo que pudiesen sobrevivir.

IRENE HOLGUÍN GÓMEZ es graduada en Bellas Artes por la Universidad Complutense de Madrid y del Máster universitario en Historia del Arte Contemporáneo y Cultura Visual (UCM/UAM). Su línea de investigación se centra en los productos culturales "femeninos", los roles de género y la cultura visual, especializándose en las representaciones visuales de la mujer en el tardofranquismo en los medios de comunicación hegemónicos. Su trabajo está entre la práctica artística y los estudios visuales. Ha recibido una beca para realizar práctica artística en el Centro Huarte y ha sido parte del colectivo Área dentro del Programa Residencias La Trasera (2014) de la UCM en el que se investigaba las intersecciones entre la universidad y la práctica. Recientemente ha trabajado en instituciones como el Museo Nacional Centro de Arte Reina Sofía y ha colaborado para proyectos de Intermediae de Matadero dentro de la convocatoria Mirador Usera.

Email: holguin.g.irene@gmail.com

67 Alicia Andreu, La construcción editorial de Corín Tellado, Vigo, Editorial Academia del Hispanismo, 2010, p. 33.

68 Aurora MorcILlo, En cuerpo y alma. Ser mujer en tiempos de Franco, Madrid, Siglo XXI, 2015, p. 445. 